European Journal of

Organic Chemistry
Postfach 101161 69451 Weinheim

Germany

Courier services:

Boschstraße 12

69469 Weinheim

Germany

Tel.: (+49) 6201606255

Fax: (+49) 6201606203

E-mail: eurjoc@wiley-vch.de

Manuscript No.

\section{Reprints/lssues}

You are entitled to a PDF for 25 hardcopies of your article. You also have the opportunity to order further issues, reprints, posters or a PDF for an unlimited number of hardcopies at the quoted rates.

Reprints of European Journal of Organic Chemistry articles are very popular. Whole issues, reprints, posters and high-quality PDFs are available at the rates given on a separate sheet. There is no surcharge for color reprints.

For overseas orders please note that you will receive your issues, reprints or posters by airmail unless you specifically opt for receiving them by surface mail. An appropriate surcharge will be levied to cover the higher postal rates.

Please bill me for:

\section{Reprints}

$$
\text { (quantity) }
$$

\section{Issues}

$$
\text { (quantity) }
$$

and send them by

$\square$ surface mail $\square$ courier service

\section{Cover Posters}

Posters are available of all the published covers in two sizes (see attached price list).

DIN A2 (42 x $60 \mathrm{~cm} / 17 \times 24 \mathrm{in})$ :

$\square$ front cover $\square$ back cover

DIN A1 (60 x 84 cm/ 24 x 33in):

$\square$ front cover $\square$ back cover

\section{PDF (unlimited number of hardcopies)}

\section{Please bill me for}

$\square$ a PDF file (high resolution)

\section{E-mail address}

Please note that posting of the final published version on the open internet is not permitted but it can be forwarded to colleagues, added to promotion packages, etc.

$\star$ Special Offer $\star$ If you order 200 or more reprints you will get a PDF file for half-price. reprints and a PDF file

Mail reprints/ issues/ posters to (no P.O. Boxes)

\section{Terms of Payment}

\section{Send INVOICE to}

\section{VAT number}

Tax-free charging can only be processed with the VAT number of the institute/company. To prevent delays with the processing, please provide us with the VAT number with this order.

\section{Purchase Order No.:}

\section{Charge the CREDIT CARD}

We accept

\section{VISA}
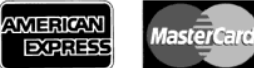

For your security please create a secured Credit Card Token which is a combination of numbers and letters that is used instead of the credit card information. Click here:

https://www.wiley-vch.de/editorial production/index.php

TOKEN

Date, Signature 


\section{WILEY-VCH}

\section{Price List (2015)}

The prices listed below are valid only for orders received in the course of 2015. Minimum order is 50 copies. Delivery time will be approximately 3 weeks after the date of publication.

If more than 500 copies are ordered, special prices are available upon request. Single issues are available to authors at a reduced price. The prices include mailing and handling charges (with the exception of the additional costs incurred for airmail delivery and courier services). The prices are exclusive of VAT.

Reprints, posters, and issues for overseas orders are shipped by airmail ( 25.00 Euro surcharge). If you would like to receive them by surface mail please indicate this on the accompanying order form (postage for shipping posters within Europe: 15.00 Euro). If you would like to use a courier service please indicate this on the order form. The cost for the courier service is 75.00 Euro.

\section{Information regarding VAT}

The charges for Reprints, Issues or Posters are considered to be "supply of goods" and therefore subject to German VAT. However, if you are an institutional customer outside Germany, the tax can be waived if you provide us with the VAT number of your company. Non-EU customers may have a VAT number starting with "EU" instead of their country code if they are registered with the EU tax authorities. If you do not have an EU VAT number and you are a taxable person doing business in a non-EU country, please provide certification from your local tax authorities confirming that you are a taxable person under local tax law. Please note that the certification must confirm that you are a taxable person and are conducting an economic activity in your country. Note: certifications confirming that you are a tax-exempt legal body (non-profit organization, public body, school, political party, etc.) in your country do not exempt you from paying German VAT.

\begin{tabular}{|c|c|c|c|c|c|c|}
\hline \multirow{2}{*}{$\begin{array}{l}\text { Reprints } \\
\text { Size (pages) }\end{array}$} & \multicolumn{6}{|c|}{ Price for orders (in Euro) } \\
\hline & 50 copies & 100 copies & 150 copies & 200 copies & 300 copies & 500 copies \\
\hline $1-4$ & 345.- & 395.- & 425.- & 445.- & 548.- & 752.- \\
\hline $5-8$ & 490.- & 573.- & 608.- & 636.- & 784.- & 1077.- \\
\hline $9-12$ & 640.- & 739.- & 786.- & 824.- & 1016.- & 1396.- \\
\hline $13-16$ & 780.- & 900.- & 958.- & 1004.- & 1237.- & 1701.- \\
\hline $17-20$ & 930.- & 1070.- & 1138.- & 1196.- & 1489.- & 2022.- \\
\hline $\begin{array}{l}\text { for every additional } \\
4 \text { pages }\end{array}$ & 147.- & 169.- & 175.- & 188.- & 231.- & 315.- \\
\hline Issues & \multicolumn{2}{|c|}{22 Euro (1 copy) } & \multicolumn{2}{|c|}{ PDF (high resolution) } & 330 Euro & \\
\hline Cover Posters & $\begin{array}{l}\text { - DIN A2 (42 } \\
\text { - DIN A1 (60 }\end{array}$ & $\begin{array}{l}\text { m/ } 17 \text { x 24in): } \\
\text { m/ } 24 \text { x 33in): }\end{array}$ & $\begin{array}{l}38 \text { Euro } \\
48 \text { Euro }\end{array}$ & & & \\
\hline
\end{tabular}

\section{$\star$ Special Offer $\star$}

If you order 200 or more reprints you will get a PDF (high resolution) for half-price. 


\title{
Simultaneous Application of Arylmethylene Acetal and Butane Diacetal Groups for Protection of Hexopyranosides: Synthesis and Chemoselective Ring- Opening Reactions
}

\author{
Mihály Herczeg, ${ }^{[a]}$ Fruzsina Demeter, ${ }^{[a, b]}$ Erika Mező, ${ }^{[a, b]}$ Máté Pap, ${ }^{[a]}$ and Anikó Borbás*[a]
}

\author{
Keywords: Carbohydrates / Acetals / Ring opening / Reduction / Protecting groups / Chemoselectivity
}

The reductive cleavage of 4,6-O-arylmethylene acetals of hexopyranosides is an effective method for the regioselective formation of a benzyl-type ether at either the C-4 or the C-6 hydroxyl group. The compatibility of this method with Ley's butane diacetal (BDA) protection was studied. 4,6-O-(211 Naphthyl)methylene, benzylidene, and p-methoxybenzylidene acetals were introduced to 2,3-O-BDA-protected gluco- and galactosides, and the bis-acetalated products were subjected to reductive acetal openings with different reagents. $\mathrm{LiAlH}_{4}-\mathrm{AlCl}_{3}$ reduced the 4,6-acetals with complete chemo- and regioselectivity to give the corresponding 4-O-ethers. The use of $\mathrm{Et}_{3} \mathrm{SiH}_{-} \mathrm{BF}_{3} \cdot \mathrm{Et}_{2} \mathrm{O}$ led to a mixture of differently reduced products, because transformation of the 4,6-acetal into the related 6 -O-ether and reduction of the BDA system into a butane-2,3-diyl group took place competitively. $\mathrm{BH}_{3} \cdot \mathrm{NMe}_{3}-\mathrm{AlCl}_{3}$ selectively cleaved the 4,6-acetal ring to give the 6 -O-ethers as the major or exclusive products.

\section{Introduction}

Carbohydrates play essential roles in a wide range of biological processes, whose survey, on a molecular level, demands the synthesis of various structurally defined oligosaccharides and glycoconjugates. The chemical synthesis of complex carbohydrates and glycoconjugates requires a careful protecting group strategy that can be used to differentiate a collection of hydroxyl groups during the synthetic process. $^{[1-5]}$ Besides their masking function, protecting groups also play a fundamental role in tuning the reactivity of the carbohydrate building blocks, and can control the stereochemical outcome of glycosylation reactions. Despite remarkable progress in the development of straightforward procedures for the rapid differentiation of the hydroxyl groups of $\mathbf{\square}((<=$ Author: do you agree with the change?)) a sugars, ${ }^{[3-9]}$ there is an ongoing need for the invention of new and reliable protecting groups, and there is also a need to study the scope and limitations of different combinations of the protecting groups currently used in oligosaccharide synthesis.

The use of cyclic acetals is one of the most efficient ways to discriminate between the different functionalities on a carbohydrate ring. ${ }^{[4,9]}$ Benzylidene-type acetals are espe-

[a] Department of Pharmaceutical Chemistry, University of Debrecen,

4010 Debrecen, PO Box 78, Hungary E-mail: borbas.aniko@pharm.unideb.hu http://pharmchem.unideb.hu/borbas_a.htm

[b] Department of Organic Chemistry, University of Debrecen, 4010 Debrecen, PO Box 20, Hungary

Supporting information for this article is available on the WWW under http://dx.doi.org/10.1002/ejoc.201500732. cially useful for the 4,6- $O$-protection of hexopyranosides because the regioselective reductive ring opening of these acetals to the corresponding benzyl-type ethers allows the release of either one of the two masked hydroxyl groups. Thus, the introduction and reductive opening of the 4,6- $O$ benzylidene, 4,6-O-p-methoxybenzylidene, or the 4,6-O-(2naphthyl)methylene acetals represents a very effective twostep method for the regioselective formation of benzyl or related ethers. The reductive transformation requires a hydride donor reagent in combination with a protic or a Lewis acid, and it can produce, depending on the reagents and conditions, either the 4-OH/6-O-arylmethyl or the 6-OH/4$O$-arylmethyl product. ${ }^{[4,10]}$

Due to the pioneering work of Ley and coworkers, vicinal trans-diequatorial diols can be selectively protected using cyclic diacetal groups, such as dispiroketal, ${ }^{[11]}$ cyclohexane diacetal, ${ }^{[12]}$ or butane diacetal (BDA) ${ }^{[13]}$ groups, of which the BDA group is the most widely used. The high regioselectivity in the protection of trans-1,2-diols in the presence of other polyols is due to the formation of the sterically less demanding trans ring junction. Moreover, the control of configuration at the two acetal centres by the operation of anomeric effects ensures complete stereoselectivity in the acetalation. The additional tuning effect on the glycosylation reactivity of the diacetal-protected building blocks in oligosaccharide assembly further enhances the synthetic utility of the 1,2-diacetals. ${ }^{[1-16]}$

Although both 4,6-O-benzylidene-type and diacetal-type protecting groups are widely used in oligosaccharide synthesis, there are only two precedents for the full protection of a carbohydrate ring by their joint application. A pentenyl glucoside was equipped with a 4,6- $O$-benzylidene group 
and a 2,3-O-dispiroketal group in the Fraser-Reid laboratory, ${ }^{[16]}$ and allyl 2,3-BDA-4,6- $O$-benzylidene-D-glucopyranoside was prepared by Pinto and coworkers. ${ }^{[17]}$ However, reductive cleavage of a 4,6-acetal in the presence of a diacetal group has not been investigated until now. The reduction of the diacetal system of a BDA group to give a butane-2,3-diyl group has been achieved by using either $\mathrm{Et}_{3} \mathrm{SiH}$ and $\mathrm{BF}_{3} \cdot \mathrm{Et}_{2} \mathrm{O}^{[18]}$ or sodium cyanoborohydride and $\mathrm{HCl} ;{ }^{[19]}$ both of these reagent systems are commonly used for the regioselective ring cleavage of 4,6-O-benzylidene acetals to give 6 - $O$-benzyl ethers. ${ }^{[20,21]}$

As the reductive opening of 4,6- $O$-benzylidene-type acetals can discriminate highly effectively between the C-4 and C-6 alcohol products, we decided to study the compatibility of this method with diacetal protection. Thus, fully protected gluco- and galactopyranosides were prepared through the simultaneous use of a butane diacetal and different benzylidene-type acetals, and reductive openings of the 4,6-arylmethylene rings were investigated using various reagents.

\section{Results and Discussion}

We started our investigations with the introduction of the acetal groups to methyl $\alpha$-D-glucopyranoside. Compound $\mathbf{1}$ was treated with 2,2,3,3-tetramethoxybutane (2) ${ }^{[13 a]}$ in boiling methanol with catalytic camphorsulfonic acid (CSA) and trimethyl orthoformate (4 equiv.) for $18 \mathrm{~h}$ to give an inseparable, ca. 3:2 mixture of the 2,3-diacetal and 3,4-diacetal regioisomers (i.e., 3 and $\mathbf{4}$ ), in accordance with literature results ${ }^{[13 a, 22]}$ (Scheme 1). This mixture was then treated with acetalating reagents, including 2-naphthaldehyde dimethyl acetal, benzaldehyde dimethyl acetal, and $p$-methoxybenzaldehyde dimethyl acetal, in DMF under $p$-tolu-
4,6-O-arylmethylene derivatives 5-7. The fully protected products could easily be separated from 2,6-diol 4, which remained unchanged in the reactions, by column chromatography, and compounds 5, 6, and 7 were isolated in 58,44 , and $33 \%$ yields, respectively, over two steps.

Among the various reagent systems that have been introduced for the reductive ring cleavage of benzylidene-type acetals, we planned to use the $\mathrm{LiAlH}_{4}-\mathrm{AlCl}_{3}$ reagent combination ${ }^{[23,24]}$ to release the 4-OH group, and the $\mathrm{Et}_{3} \mathrm{SiH}-$ $\mathrm{BF}_{3} \cdot \mathrm{Et}_{2} \mathrm{O}$ combination ${ }^{[19]}$ to liberate the 6-OH group, because these reagents are often reliable in providing the corresponding alkyl derivatives in high yield and with high regioselectivity. Thus, 4,6-O-(2-naphthyl)methylene derivative 5 was treated with a mixture of $\mathrm{LiAlH}_{4}$ and $\mathrm{AlCl}_{3}$ in a 3:1 ratio (forming $\left.\mathrm{AlH}_{3}\right),{ }^{[24,25]}$ to give 4-O-(2-naphthyl)methyl ether $\mathbf{8}$ exclusively in $86 \%$ yield. Reductive cleavage of the 4,6-O-( $p$-methoxy)benzylidene acetal of 7 using the same $\mathrm{AlH}_{3}$ reagent also proceeded with complete selectivity to give 10 in $89 \%$ yield. For the opening of the benzylidene ring of 6, an equimolar mixture of $\mathrm{LiAlH}_{4}$ and $\mathrm{AlCl}_{3}$ (forming $\left.\mathrm{AlH}_{2} \mathrm{Cl}\right)^{[24]}$ was used, and the required 4-O-benzyl ether (i.e, 9) was obtained in $74 \%$ yield. The above reductive transformations of the different 4,6-acetals turned out to be completely chemoselective; the $\mathrm{LiAlH}_{4}-\mathrm{AlCl}_{3}$ system did not affect the 2,3-O-butane diacetal protecting group. To achieve the opposite regioselectivity during the 4,6-acetal cleavage, compounds 5-7 were treated with $\mathrm{Et}_{3} \mathrm{SiH}$ and $\mathrm{BF}_{3} \cdot \mathrm{Et}_{2} \mathrm{O}$ (Scheme 2). It should be noted that this reagent combination, using acetonitrile as the solvent, has been used by Shing et al. on a BDA-protected arabinoside derivative for the reduction of the diacetal system into a butane2,3-diyl group in an $8 \mathrm{~h}$ reaction. ${ }^{[18]}$ Bearing in mind the considerably higher rate of the reductive cleavage of the benzylidene ring with this reagent system, ${ }^{[19,26]}$ we expected that the BDA moiety could survive the arylmethylene-opening reactions. Compound $\mathbf{5}$ was treated with $\mathrm{Et}_{3} \mathrm{SiH}$

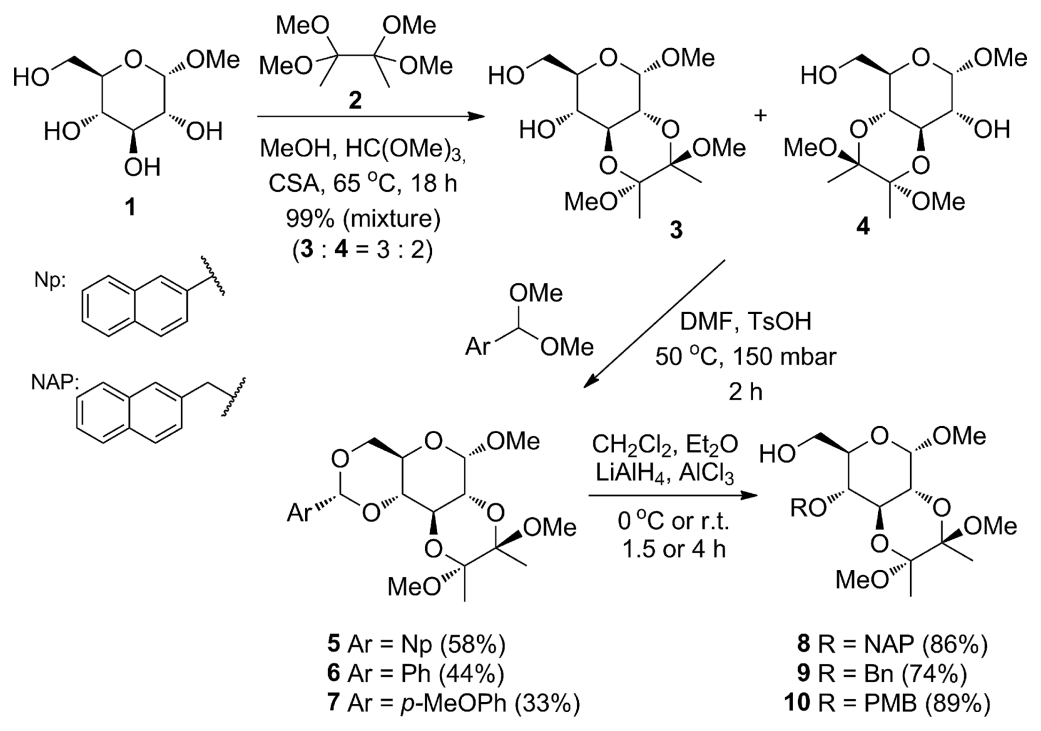

Scheme 1. Double acetalation of methyl $\alpha$-D-glucopyranoside (1), and reductive cleavage of the 4,6-O-arylmethylene rings of 5-7 with $\mathrm{LiAlH}_{4}-\mathrm{AlCl}_{3}$. 
(12 equiv.) and $\mathrm{BF}_{3} \cdot \mathrm{Et}_{2} \mathrm{O}$ (2 equiv.) in anhydrous dichloromethane at $0{ }^{\circ} \mathrm{C}$, and after $45 \mathrm{~min}$ TLC showed the almost complete consumption of the starting material and the formation of one major product, together with some polar degradation compounds. Unfortunately, the seemingly single product turned out to be an inseparable 3:2 mixture of the desired 11a and its BDA-reduced counterpart 11b. Similarly, reductive cleavage of the 4,6-O-benzylidene acetal of 6 in the presence of a 2,3-BDA moiety with $\mathrm{Et}_{3} \mathrm{SiH}$ and $\mathrm{BF}_{3} \cdot \mathrm{Et}_{2} \mathrm{O}$ showed only moderate chemoselectivity. Although the opening reaction of the 4,6-acetal ring dominated again, reduction of the butane diacetal system into a butane-2,3-diyl group took also place to some extent, to result in a 1:1 mixture of $\mathbf{1 2} \mathbf{a}$ and $\mathbf{1 2 b}$, which could not be separated.
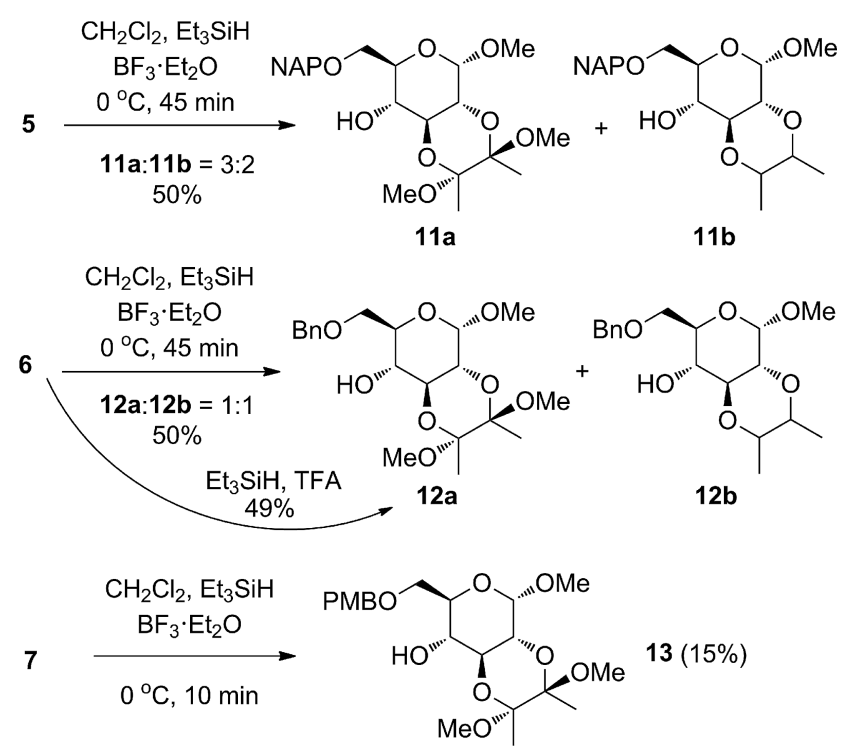

Scheme 2. Reductive opening of the 4,6-O-acetal rings of 5-7 using $\mathrm{Et}_{3} \mathrm{SiH}$ in combination with $\mathrm{BF}_{3} \cdot \mathrm{Et}_{2} \mathrm{O}$ or TFA.

Treatment of 4,6-O-( $p$-methoxy)benzylidene derivative 7 with the same reagent combination led to complete loss of the 4,6-acetal ring. When the reaction was repeated using a lesser amount ( 1 equiv.) of $\mathrm{BF}_{3} \cdot \mathrm{Et}_{2} \mathrm{O}$, chemoselective reductive opening of the 4,6-acetal took place to give the desired 6-O-( $p$-methoxy)benzyl (PMB) derivative (i.e., 13) in $15 \%$ yield. Reduction of the BDA group was not observed; the yield of $\mathbf{1 3}$ was low due to the formation of substantial amounts of polar degradation products. We also tested the ring opening of the 4,6-benzylidene ring of compound 6 using a combination of $\mathrm{Et}_{3} \mathrm{SiH}$ ( 5 equiv.) and trifluoroacetic acid (TFA; 5 equiv.). ${ }^{[27]}$ Although this reduction gave the desired 6-ether derivative (i.e., 12a) chemoselectively, the $49 \%$ yield was unsatisfactory.

$\mathrm{BH}_{3} \cdot \mathrm{NMe}_{3}-\mathrm{AlCl}_{3}$, used in tetrahydrofuran as solvent, is an effective reagent for the regioselective opening of 4,6- $O$ benzylidene ${ }^{[28]}$ or 4,6-O-(2-naphthyl)methylene ${ }^{[29]}$ acetals of hexopyranosides to give the corresponding 6-O-ethers. (Note that the use of toluene with this reagent results in a reversal of the regioselectivity.) Therefore, compounds 5-7 were treated with $\mathrm{BH}_{3} \cdot \mathrm{NMe}_{3}$ (6 equiv.) and $\mathrm{AlCl}_{3}$ (6 equiv.) in $\mathrm{THF}$ at room temperature. We were pleased to find that this reagent system cleaved the 4,6-acetals with complete chemoselectivity, without affecting the diacetal system of the BDA group (Scheme 3). However, the regioselectivity of the reaction was strongly influenced by the type of the acetal. Starting from (2-naphthyl)methylene acetal 5, 6- $O$ ether 11a was formed exclusively in a yield of $75 \%$. The ring opening of the benzylidene acetal also proceeded with good selectivity to give the regioisomeric 6- and 4- $O$-ethers in a ratio of 7:2, while the reductive cleavage of the ( $p$-methoxy)benzylidene acetal took place without notable regioselectivity to give a ca. 1:1 mixture of the 6- and 4- $O$-PMB derivatives.

Next, the double acetalation and 4,6-acetal opening procedure was studied on methyl $\beta$-D-glucopyranoside. This time, following the procedure described by Hense et al., ${ }^{[13 b]}$ commercially available butane-2,3-dione was used to introduce the BDA protecting groups. Thus, compound 14 was treated with butane-2,3-dione and trimethyl orthoformate in the presence of CSA in boiling methanol for $18 \mathrm{~h}$ to give an inseparable mixture of the 2,3- and 3,4-BDA-protected $\beta$-methyl derivatives, along with a small amount of their anomers (15 and 16; Scheme 4). Similar anomerisation during the BDA-protection of methyl $\alpha$-D-galactopyranoside was also observed by Frost and coworkers. ${ }^{[13 a]}$ The resulting mixture was treated directly with benzaldehyde dimethyl acetal in the presence of a catalytic amount of $\mathrm{TsOH}$ to give fully protected derivative $\mathbf{1 7}$ as a 10:1 anomeric mixture in $54 \%$ yield.

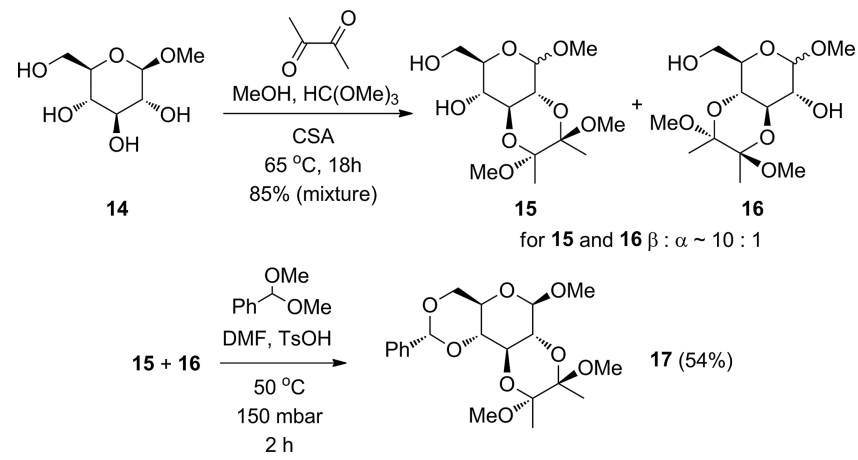

Scheme 4. Double acetalation of methyl $\beta$-D-glucopyranoside (14).

The pure $\beta$-anomer of $\mathbf{1 7}$ could be obtained in crystalline form, and its structure was confirmed by X-ray crystallography (Figure 1).

Reductive cleavage of the 4,6-O-benzylidene ring of $\mathbf{1 7}$ with a mixture of $\mathrm{LiAlH}_{4}$ and $\mathrm{AlCl}_{3}$ proceeded again with complete selectivity to give 4-O-benzyl ether $\mathbf{1 8}$ in $83 \%$ yield. Attempted transformation of $\mathbf{1 7}$ into the corresponding 6-O-ether derivative using $\mathrm{Et}_{3} \mathrm{SiH}$ (12 equiv.) and $\mathrm{BF}_{3} \cdot \mathrm{Et}_{2} \mathrm{O}$ (2 equiv.) gave an inseparable 1:1 mixture of the desired 19a and its reduced butane-2,3-diyl counterpart 19b in $48 \%$ overall yield. When the reaction was repeated using 1 equiv. of $\mathrm{BF}_{3} \cdot \mathrm{Et}_{2} \mathrm{O}$, a higher yield was achieved, but the ratio of products 19a and $19 \mathrm{~b}$ hardly changed.

$\mathrm{BH}_{3} \cdot \mathrm{NMe}_{3}-\mathrm{AlCl}_{3}$ proved to be a very efficient reagent combination for the cleavage of the 4,6-benzylidene ring. 


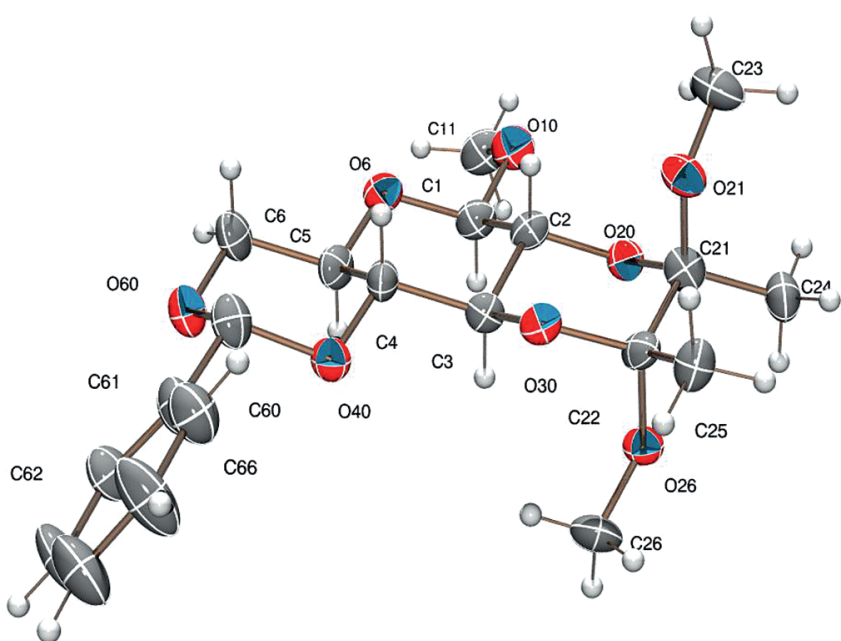

Figure 1. ORTEP view of 17.

The reduction proceeded with complete chemo- and regioselectivity to give 6-O-ether 19a in $85 \%$ yield (Scheme 5).

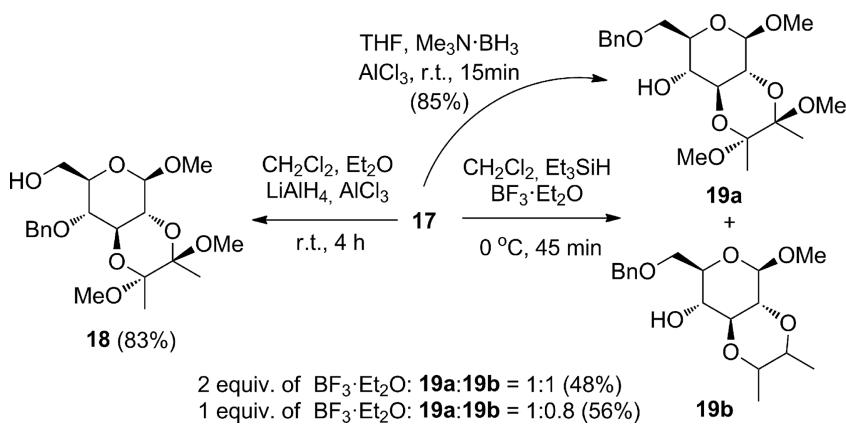

Scheme 5. Reductive openings of the 4,6-acetal of 17.

Phenyl 1-thio- $\beta$-D-glucopyranoside (20) was also included in our studies. Compound 20 was treated with 2,2,3,3-tetramethoxybutane (2), trimethyl orthoformate, and methanol, in the presence of CSA, and the resulting regioisomeric diacetals (i.e., $\mathbf{2 1}^{[30]}$ and $\mathbf{2 2}^{[30]}$ ) were separated to give the required 2,3-BDA derivative (i.e., 21) in 39\% acetal was introduced to the 4,6-position by using the corresponding dimethyl acetal reagent in DMF, with $\mathrm{TsOH}$ catalysis, to give the expected double acetalated product (i.e., $\mathbf{2 3}$ ) in $68 \%$ yield; unreacted 21 was also recovered in $21 \%$ yield (Scheme 6).

Reductive cleavage of the 4,6-O-(2-naphthyl)methylene acetal of 23 with a mixture of $\mathrm{LiAlH}_{4}$ and $\mathrm{AlCl}_{3}$ proceeded with complete selectivity to give the expected 4- $O$-ether (i.e., $24^{[31]}$ ) in $79 \%$ yield. Transformation of 23 into 6-O-NAP derivative 25 was successfully carried out, without affecting the diacetal group, by using $\mathrm{Et}_{3} \mathrm{SiH}$ (12 equiv.) and $\mathrm{BF}_{3} \cdot \mathrm{Et}_{2} \mathrm{O}$ ( 1 equiv.) as the reducing agents. The $\mathrm{BH}_{3} \cdot \mathrm{NMe}_{3}-\mathrm{AlCl}_{3}$ reagent also opened the 4,6-acetal with complete chemo- and regioselectivity to give the 6- $O$-ether in an excellent $82 \%$ yield (Scheme 7 ).

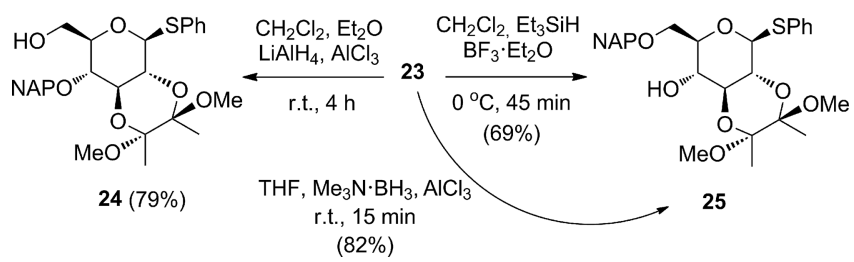

Scheme 7. Reductive 4,6-acetal-cleavage reactions of $\mathbf{2 3}$.

In order to explore the reductive cleavage of a cis-annelated acetal ring in the presence of the BDA protecting group, double acetalation of methyl $\alpha$-D-galactopyranoside 26 was also executed. The synthesis of the bis-acetalated 28 started from methyl $\alpha$-D-galactopyranoside (26) (Scheme 8). Treatment of $\mathbf{2 6}$ with butane-2,3-dione and trimethyl orthoformate in boiling methanol in the presence of catalytic $\mathrm{BF}_{3} \cdot \mathrm{Et}_{2} \mathrm{O}$ led to the regioselective formation of 2,3-O-BDAprotected galactopyranoside $27,{ }^{[13 a]}$ which was then treated with benzaldehyde dimethyl acetal in DMF using $\mathrm{TsOH}$ as a catalyst to give fully protected derivative $\mathbf{2 8}$ in $67 \%$ yield.

Reductive cleavage of the 4,6-O-benzylidene ring of $\mathbf{2 8}$ using the $\mathrm{LiAlH}_{4}-\mathrm{AlCl}_{3}$ reagent combination gave 4-Obenzyl ether 29 with complete chemo- and regioselectivity in $84 \%$ yield. Our attempt to synthesize the BDA-protected 6- $O$-ether derivative using $\mathrm{Et}_{3} \mathrm{SiH}$ and $\mathrm{BF}_{3} \cdot \mathrm{Et}_{2} \mathrm{O}$ was unsuc-

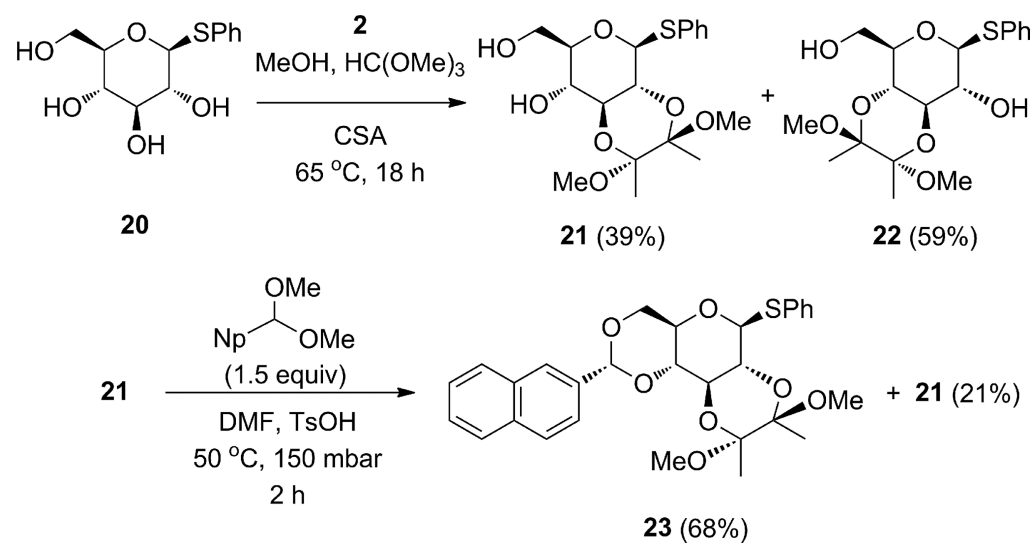

Scheme 6. Full protection of phenyl 1-thio- $\beta$-D-glucopyranoside (20) by two consecutive acetal-exchange reactions. 

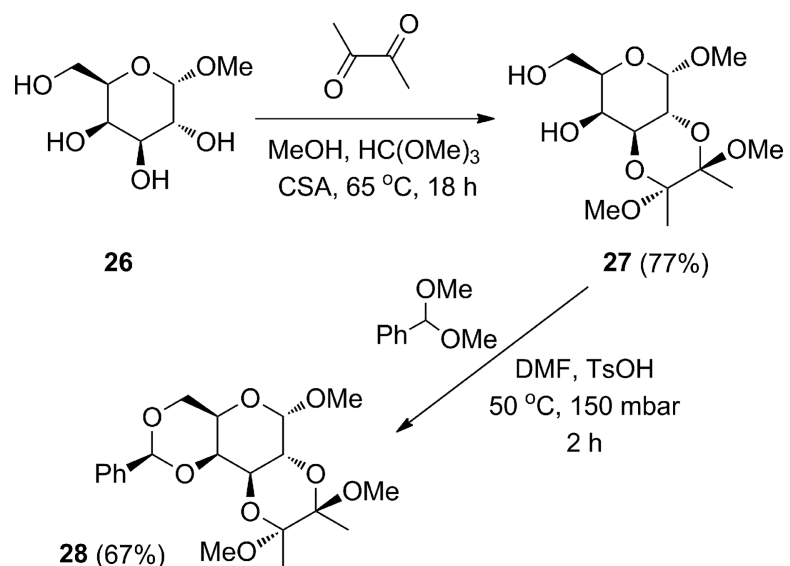

Scheme 8. Double acetalation of $\mathbf{2 6}$

cessful. The reaction of $\mathbf{2 8}$ with $\mathrm{Et}_{3} \mathrm{SiH}$ in the presence of $\mathrm{BF}_{3} \cdot \mathrm{Et}_{2} \mathrm{O}$ (2 equiv.) showed a very low conversion after $3 \mathrm{~h}$; the only product was 30, in which both the benzylidene acetal and the butane diacetal were reduced. Interestingly, when half of the amount of the Lewis acid was used, the reaction took place with opposite chemoselectivity to that expected. Only the butane diacetal system was reduced to give 31, bearing an unchanged 4,6-acetal ring, in 18\% yield (Scheme 9). The combination of $\mathrm{BH}_{3} \cdot \mathrm{NMe}_{3}$ with $\mathrm{AlCl}_{3}$ proved to be an efficient reagent system to reduce the cisannelated 4,6-benzylidene ring of $\mathbf{2 8}$ without affecting the butane diacetal system. The reductive cleavage also showed good regioselectivity to give $6-O$-ether $\mathbf{3 2}$ in $73 \%$ yield, together with the regioisomeric $4-O$-ether in $7 \%$ yield.

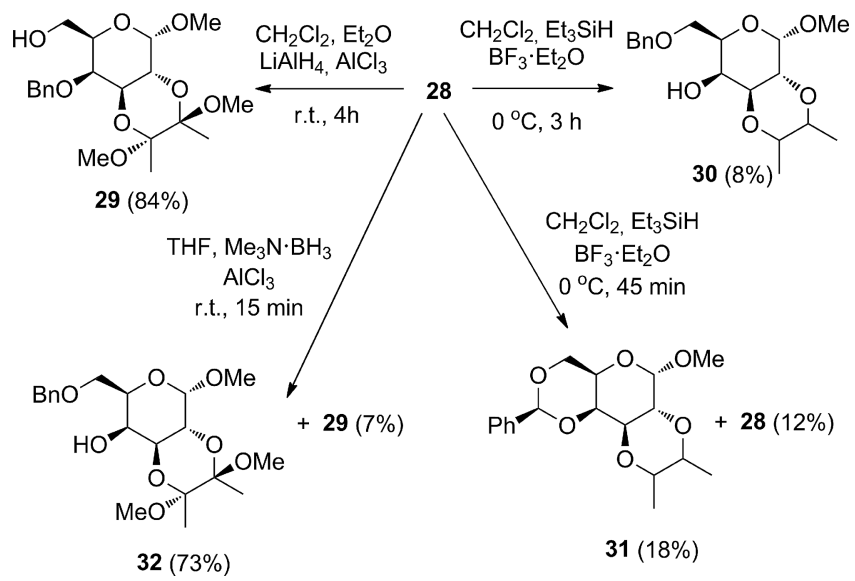

Scheme 9. Reductive cleavage of the benzylidene ring of $\mathbf{2 8}$ with different reagents.

\section{Conclusions}

In summary, three reagent systems, $\mathrm{LiAlH}_{4}-\mathrm{AlCl}_{3}$, $\mathrm{BH}_{3} \cdot \mathrm{NMe}_{3}-\mathrm{AlCl}_{3}$, and $\mathrm{Et}_{3} \mathrm{SiH}-\mathrm{BF}_{3} \cdot \mathrm{Et}_{2} \mathrm{O}$, have been used for the reductive cleavage of 4,6-O-benzylidene-type acetals of glucoside and galactoside derivatives bearing a 2,3-OBDA protecting group. Using the $\mathrm{LiAlH}_{4}-\mathrm{AlCl}_{3}$ reagent combination, chemo- and regioselective reduction of the 4,6-acetal and highly efficient formation of the corresponding 4-O-ether were observed in all cases.

The reactions with $\mathrm{BH}_{3} \cdot \mathrm{NMe}_{3}-\mathrm{AlCl}_{3}$ in THF also showed complete chemoselectivity; the butane diacetal moieties remained intact, and exclusive cleavage of the 4,6-acetals took place to give the expected 6-O-ethers with varying regioselectivity. The reduction of the 4,6-O-(2-naphthyl)methylene acetals gave the 6- $O$-NAP ethers exclusively, while reduction of the $p$-methoxybenzylidene derivative yielded the 4-O- and 6-O-PMB ethers in almost equal amounts. The benzylidene acetals could be transformed into the 6-O-benzyl ethers with high or complete regioselectivity, depending on the anomeric configuration.

$\mathrm{Et}_{3} \mathrm{SiH}-\mathrm{BF}_{3} \cdot \mathrm{Et}_{2} \mathrm{O}$ proved to be an inappropriate reagent system for the chemoselective transformation of 4,6-acetals into the corresponding 4-O-ethers in the presence of a 2,3$O$-BDA moiety. As well as the expected ring-opening reaction, hydrolysis of the 4,6-acetal ring and reduction of the butane diacetal system to give a butane-2,3-diyl group took place competitively to give a complex mixture, from which the desired 4- $O$-ether-2,3-O-BDA derivative could not be isolated in pure form.

Taking advantage of the chemoselective acetal openings, dually acetalated glycosyl donors such as thioglucoside $\mathbf{2 3}$ can be regarded as useful building blocks for the preparation of 1,2-cis- $\alpha$-linked oligoglycosyl fragments elongated at the $\mathrm{C}-4$ or $\mathrm{C}-6$ positions. It is worth noting that $2,3-\mathrm{O}$ BDA-protected donors represent a different level of reactivity in glycosylation reactions and allow an orthogonal deprotection method compared to their widely used etherprotected counterparts. Therefore, the simultaneous use of arylmethylene acetal and butane diacetal groups for the protection of hexopyranosides would offer an attractive alternative to the protecting group systems used currently in oligosaccharide synthesis.

The synthesis of orthogonally protected maltooligosaccharide derivatives by using this simultaneous acetal-diacetal protecting group approach is in progress, and the results will be reported in due course.

\section{Experimental Section}

General Methods: Optical rotations were measured at room temperature with a Perkin-Elmer 241 automatic polarimeter. TLC analysis was carried out on Kieselgel $60 \mathrm{~F}_{254}$ (Merck) silica gel plates, which were visualized by immersing in a sulfuric acid solution $(5 \%$ in $\mathrm{EtOH})$ followed by heating. Column chromatography was carried out on silica gel 60 (Merck $0.063-0.200 \mathrm{~mm}$ ), flash column chromatography was carried out on silica gel 60 (Merck 0.04 $0063 \mathrm{~mm}$ ). Organic solutions were dried with $\mathrm{MgSO}_{4}$ and concentrated under vacuum. ${ }^{1} \mathrm{H}$ NMR (360 and $400 \mathrm{MHz}$ ) and ${ }^{13} \mathrm{C}$ NMR (90.54 and 100.28 MHz) spectra were recorded with Bruker DRX360 and Bruker DRX-400 spectrometers. Chemical shifts are referenced to $\operatorname{SiMe}_{4}\left(\delta=0.00 \mathrm{ppm}\right.$ for $\left.{ }^{1} \mathrm{H}\right)$ and to the solvent signal $\left(\mathrm{CDCl}_{3}: \delta=77.00 \mathrm{ppm}\right.$ for $\left.{ }^{13} \mathrm{C}\right)$. MS (MALDI-TOF) analysis was carried out in positive reflectron mode with a BIFLEX III mass spectrometer (Bruker, Germany) with delayed-ion extraction. The matrix solution was a saturated solution of 2,4,6-trihydroxy-acetophenone (THAP) in MeCN. Elemental analysis $(\mathrm{C}, \mathrm{H}, \mathrm{S})$ was car- 
ied out with an Elementar Vario MicroCube instrument. X-ray diffraction data for compound $\mathbf{1 7}$ were collected with a BrukerNonius MACH3 diffractometer at $293 \mathrm{~K}$, using Mo $K_{\alpha}$ radiation $\lambda$ $=0.71073 \AA$. All non-hydrogen atoms were refined anisotropically.

CCDC-1056686 contains the supplementary crystallographic data

351 for compound 17. These data can be obtained free of charge from The Cambridge Crystallographic Data Centre via www.ccdc.cam. ac.uk/data_request/cif.

General Method A: Formation of butanedione dimethyl acetal using 2,2,3,3-tetramethoxybutane; 3, 4, 21, and 22. A suspension of tetraol 1 or $\mathbf{2 0}$ (2-5 mmol, 1.0 equiv.) in a solution of 2,2,3,3tetramethoxybutane (1.2 equiv.) and trimethyl orthoformate (4.0 equiv.) in methanol $(2-5 \mathrm{~mL} / \mathrm{mmol}$ of tetraol) was treated with (+)-camphor-10-sulfonic acid ( 0.05 equiv.). The mixture was stirred under argon at $65^{\circ} \mathrm{C}$ for $18 \mathrm{~h}$. The cooled reaction mixture was

361 then treated with powdered $\mathrm{NaHCO}_{3}$ (ca. $0.5 \mathrm{~g}$ ), and concentrated under reduced pressure. Purification by column chromatography on silica gel gave the protected carbohydrates.

General Method B: Formation of butanedione dimethyl acetal using butane-2,3-dione; 15, 16, and 27. (+)-Camphor-10-sulfonic acid ( 0.1 equiv.) was added to a solution of tetraol 14 or 26 (5.00 mmol), butane-2,3-dione (1.1 equiv.), and trimethyl orthoformate (4.0 equiv.) in anhydrous methanol $(15.0 \mathrm{~mL})$. The mixture was stirred at $65^{\circ} \mathrm{C}$ for $18 \mathrm{~h}$, and then it was neutralized by the addition of triethylamine $(100 \mu \mathrm{L})$. The mixture was concentrated under reduced pressure, and purified by column chromatography on silica gel.

General Method C: Formation of the 4,6- $O$-acetal ring; 5, 6, 7, 17, 23, and 28. A regioisomeric mixture of diols $(3+4$ or $15+16)$ or diol 21 or $27(3.00 \mathrm{mmol})$ was dissolved in anhydrous DMF $(5.0 \mathrm{~mL})$, and naphthaldehyde dimethyl acetal, benzaldehyde dimethyl acetal, or p-methoxybenzaldehyde dimethyl acetal (1.11.5 equiv.) and $\mathrm{TsOH}$ ( 0.25 or 0.10 equiv.) were added. The mixture was stirred at $50{ }^{\circ} \mathrm{C}$ under reduced pressure (150 mbar). After $2 \mathrm{~h}$, the reaction mixture was neutralized by the addition of triethyl-

381 amine, and then concentrated in vacuo. Purification by column chromatography on silica gel gave the diacetal derivatives.

General Method D: Reductive ring-opening reaction of the 4,6- $O$ acetal with $\mathrm{LiAlH}_{4}-\mathrm{AlCl}_{3} ; \mathbf{8}, \mathbf{9}, \mathbf{1 0}, \mathbf{1 8}, \mathbf{2 4}$, and 29. A diacetal derivative $\mathbf{5}, \mathbf{6}, \mathbf{7}, \mathbf{1 7}, \mathbf{2 3}$, or $28(1.00 \mathrm{mmol})$ was dissolved in anhydrous

$386 \mathrm{CH}_{2} \mathrm{Cl}_{2}$ and anhydrous $\mathrm{Et}_{2} \mathrm{O}$. $\mathrm{LiAlH}_{4}$ was added, and then a solution of $\mathrm{AlCl}_{3}$ in anhydrous $\mathrm{Et}_{2} \mathrm{O}$ was added $\square \square((<=$ Author: please check the first two sentences of this paragraph read correctly)) $\square$. The reaction mixture was stirred at $0{ }^{\circ} \mathrm{C}(\mathbf{1 0}: 1.5 \mathrm{~h})$ or room temperature $(\mathbf{8}, \mathbf{9}, \mathbf{1 8}, \mathbf{2 4}$, and 29: $4 \mathrm{~h})$. The reaction mixture was 391 diluted with EtOAc $(20.0 \mathrm{~mL})$ and $\mathrm{H}_{2} \mathrm{O}(5.0 \mathrm{~mL})$, filtered, washed with EtOAc, and concentrated $\mathbf{\square}((<=$ Author: Please clarify this sentence: what was filtered, what was washed, and what was concentrated?)) $\square$. Purification by column chromatography on silica gel gave the corresponding 4-O-ether derivative

396 General Method E: (Reductive ring-opening reaction of the 4,6- $O$ acetal with $\mathrm{Et}_{3} \mathrm{SiH}-\mathrm{BF}_{3} \cdot \mathrm{Et}_{2} \mathrm{O} ; \mathbf{1 1} \mathbf{a}, \mathbf{b}, \mathbf{1 2 a}, \mathbf{b}, \mathbf{1 3}, \mathbf{1 9} \mathbf{a}, \mathbf{b}, 25, \mathbf{3 0}$, and 31). A 4,6-O-acetal derivative $5,6,7, \mathbf{1 7}, \mathbf{2 3}$, or $28(0.60 \mathrm{mmol})$ was dissolved in anhydrous $\mathrm{CH}_{2} \mathrm{Cl}_{2}(4.0 \mathrm{~mL})$, and the solution was cooled to $0{ }^{\circ} \mathrm{C}$. $\mathrm{Et}_{3} \mathrm{SiH}$ (12.0 equiv.) and $\mathrm{BF}_{3} \cdot \mathrm{Et}_{2} \mathrm{O}$ (2.0 or 4011.0 equiv.) were added. The reaction mixture was stirred for $10 \mathrm{~min}$ (13), or $45 \mathrm{~min}(\mathbf{1 1 a}, \mathbf{b}, \mathbf{1 2 a}, \mathbf{b}, \mathbf{1 9 a}, \mathbf{b}, \mathbf{2 5}$, and 31), or $3 \mathrm{~h} \mathrm{(30).} \mathrm{The}$ mixture was diluted with $\mathrm{CH}_{2} \mathrm{Cl}_{2}(100 \mathrm{~mL})$, washed with saturated aqueous $\mathrm{NaHCO}_{3}(2 \times 10.0 \mathrm{~mL})$, dried with $\mathrm{MgSO}_{4}$, and concentrated. The crude product was purified by column chromatography on silica gel.
General Method F: (Reductive ring-opening reaction of the 4,6-Oacetal with $\mathrm{BH}_{3} \cdot \mathrm{NMe}_{3}-\mathrm{AlCl}_{3} ; 11 \mathbf{a}, 12 \mathbf{a}, 13,19 \mathbf{a}, 25$, and 32). A 4,6- $O$-acetal derivative $5, \mathbf{6}, 7, \mathbf{1 7}, \mathbf{2 3}$, or $28(1.00 \mathrm{mmol})$ was dissolved in anhydrous THF $(3.0 \mathrm{~mL})$, and molecular sieves ( $4 \AA$; $0.5 \mathrm{~g})$ and $\left(\mathrm{CH}_{3}\right)_{3} \mathrm{~N} \cdot \mathrm{BH}_{3}(6.0$ equiv.) were added. The mixture was stirred for $30 \mathrm{~min}$ at room temperature. After $30 \mathrm{~min}, \mathrm{AlCl}_{3}$ (6.0 equiv.) was added, and the reaction mixture was stirred at room temperature for $15 \mathrm{~min}$. The mixture was diluted with $\mathrm{CH}_{2} \mathrm{Cl}_{2}(100 \mathrm{~mL})$, washed with water $(2 \times 15.0 \mathrm{~mL})$, dried with $\mathrm{MgSO}_{4}$, and concentrated. The crude product was purified by column chromatography on silica gel.

Methyl 2,3-O-(2', $3^{\prime}$-Dimethoxybutane-2', $3^{\prime}$-diyl)- $\alpha$-D-glucopyranoside (3) and Methyl 3,4-O-(Dimethoxybutane-2', $3^{\prime}$-diyl)- $\alpha$-D-glucopyranoside (4): Compound 1 (20.0 g, $100.0 \mathrm{mmol})$ was converted into 3 and $\mathbf{4}$ by method A. Purification by column chromatography on silica gel ( $n$-hexane/acetone, 1:1) gave compounds $\mathbf{3}$ and $\mathbf{4}$ $(31.8 \mathrm{~g}, 99 \%$, inseparable mixture) as a white foam.

Data for 3 (from the reaction mixture to prepare 13 from 7 by general method E): White foam. $[\alpha]_{\mathrm{D}}^{24}=-54.3\left(c=0.09, \mathrm{CHCl}_{3}\right)$; ref. $^{[22]}[\alpha]_{\mathrm{D}}^{24}=-58(c=1.1) . R_{\mathrm{f}}=0.33(n$-hexane/acetone, $1: 1) .{ }^{1} \mathrm{H}$

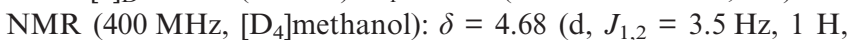
$1-\mathrm{H}), 3.91\left(\mathrm{dd}, J_{3,4}=8.9, J_{2,3}=10.2 \mathrm{~Hz}, 1 \mathrm{H}, 3-\mathrm{H}\right), 3.80\left(\mathrm{dd}, J_{5,6}\right.$ $\left.=2.1, J_{\mathrm{gem}}=11.9 \mathrm{~Hz}, 1 \mathrm{H}, 6-\mathrm{Ha}\right), 3.70\left(\mathrm{dd}, J_{5,6}=5.1, J_{\mathrm{gem}}=\right.$ $11.9 \mathrm{~Hz}, 1 \mathrm{H}, 6-\mathrm{Hb}), 3.64\left(\mathrm{dd}, J_{1,2}=3.6, J_{2,3}=10.3 \mathrm{~Hz}, 1 \mathrm{H}, 2-\right.$ $\mathrm{H}), 3.54-3.52$ (m, $1 \mathrm{H}, 5-\mathrm{H}), 3.51-3.46(\mathrm{~m}, 1 \mathrm{H}, 4-\mathrm{H}), 3.41$ (s, $3 \mathrm{H}$, $\left.\mathrm{C}-1-\mathrm{OCH}_{3}\right), 3.28,3.23\left(2 \mathrm{~s}, 6 \mathrm{H}, 2 \mathrm{OCH}_{3} \mathrm{BDA}\right), 1.28,1.27(2 \mathrm{~s}, 6$ $\mathrm{H}, 2 \mathrm{CH}_{3}$ BDA) ppm. ${ }^{13} \mathrm{C} \mathrm{NMR}\left(100 \mathrm{MHz},\left[\mathrm{D}_{4}\right]\right.$ methanol): $\delta=$ 101.1, 100.7 (2 C, $2 \mathrm{C}_{\mathrm{q}}$ BDA), 99.3 (1 C, C-1), 74.4, 70.7, 69.8, 68.8 (4 C, skeleton carbons), 62.3 (1 C, C-6), 55.4 (1 C, C-1-OCH $\mathrm{H}_{3}$, 48.2, 48.1 (2 C, $\left.2 \mathrm{OCH}_{3} \mathrm{BDA}\right), 18.1,17.8$ (2 C, $\left.2 \mathrm{CH}_{3} \mathrm{BDA}\right) \mathrm{ppm}$. MS (MALDI-TOF): $m / z=331.17[\mathrm{M}+\mathrm{Na}]^{+} . \mathrm{C}_{13} \mathrm{H}_{24} \mathrm{O}_{8}(308.15)$ : calcd. C 50.64, H 7.85; found C 50.69, H 7.89

Data for 4 (from the reaction to prepare 5): White foam. $[\alpha]_{\mathrm{D}}^{24}=$ $+188.8\left(c=0.37, \mathrm{CHCl}_{3}\right)$; ref. ${ }^{[32]}[\alpha]_{\mathrm{D}}^{24}=+258(c=1.2) . R_{\mathrm{f}}=0.33$ (n-hexane/acetone, 1:1). ${ }^{1} \mathrm{H}$ NMR $\left(360 \mathrm{MHz}, \mathrm{CDCl}_{3}\right): \delta=4.78(\mathrm{~d}$, $\left.J_{1,2}=3.7 \mathrm{~Hz}, 1 \mathrm{H}, 1-\mathrm{H}\right), 3.92(\mathrm{t}, J=9.8 \mathrm{~Hz}, 1 \mathrm{H}), 3.84-3.61(\mathrm{~m}, 5$ $\mathrm{H}), 3.42$ (s, $\left.3 \mathrm{H}, \mathrm{C}-1-\mathrm{OCH}_{3}\right), 3.34$ (d, $\left.J=6.9 \mathrm{~Hz}, 1 \mathrm{H}, \mathrm{OH}\right), 3.29$, $3.25\left(2 \mathrm{~s}, 6 \mathrm{H}, 2 \mathrm{OCH}_{3} \mathrm{BDA}\right), 3.13(\mathrm{~s}, 1 \mathrm{H}, \mathrm{OH}), 1.31,1.28(2 \mathrm{~s}, 6$ $\left.\mathrm{H}, 2 \mathrm{CH}_{3} \mathrm{BDA}\right) \mathrm{ppm} .{ }^{13} \mathrm{C} \mathrm{NMR}\left(90 \mathrm{MHz}, \mathrm{CDCl}_{3}\right): \delta=99.3(1 \mathrm{C}$, C-1), 99.0, 98.9 (2 C, $2 \mathrm{C}_{\mathrm{q}}$ BDA), 69.4, 69.3, 69.1, 65.4 (4 C, skeleton carbons), 60.2 (1 C, C-6), $54.6\left(1 \mathrm{C}, \mathrm{C}-1-\mathrm{OCH}_{3}\right), 47.3(2 \mathrm{C}, 2$ $\mathrm{OCH}_{3}$ BDA), 17.1, 17.0 (2 C, $2 \mathrm{CH}_{3}$ BDA) ppm. MS (MALDITOF): $m / z=331.29[\mathrm{M}+\mathrm{Na}]^{+} \cdot \mathrm{C}_{13} \mathrm{H}_{24} \mathrm{O}_{8}$ (308.15): calcd. C 50.64, H 7.85; found C 50.68, H 7.90.

Methyl 2,3-O-(2',3'-Dimethoxybutane-2', $3^{\prime}$-diyl)-4,6-O-(2-naphthyl)methylene- $\alpha$-D-glucopyranoside (5): A mixture of compounds 3 and 4 (1.00 g, $3.24 \mathrm{mmol})$ was converted into 5 by method $\mathrm{C}$ using naphthaldehyde dimethyl acetal $(0.98 \mathrm{~g}, 4.86 \mathrm{mmol}, 1.5$ equiv. $)$ and $\mathrm{TsOH}(0.25$ equiv.). The crude product was purified by silica gel chromatography ( $n$-hexane/acetone, $7: 3$ ) to give 5 (884 mg, 58\%) as a colourless syrup, and unreacted $4(570 \mathrm{mg}, 39 \%)$ as a colourless syrup. $[\alpha]_{\mathrm{D}}^{24}=-29.1\left(c=0.03, \mathrm{CHCl}_{3}\right) . R_{\mathrm{f}}=0.36(n$-hexane/acetone, 7:3). ${ }^{1} \mathrm{H}$ NMR (360 MHz, $\left.\mathrm{CDCl}_{3}\right): \delta=7.94-7.43$ (m, $7 \mathrm{H}$, arom), $5.67\left(\mathrm{~s}, 1 \mathrm{H}, \mathrm{H}_{\mathrm{ac}}\right), 4.77\left(\mathrm{~d}, J_{1,2}=3.5 \mathrm{~Hz}, 1 \mathrm{H}, 1-\mathrm{H}\right), 4.33-4.26(\mathrm{~m}$, $2 \mathrm{H}, 6-\mathrm{Ha}, 4-\mathrm{H}), 3.90\left(\mathrm{dd}, J_{1,2}=3.6, J_{2,3}=J_{5,6}=9.7 \mathrm{~Hz}, 2 \mathrm{H}, 2-\right.$ $\mathrm{H}, 6-\mathrm{Hb}), 3.83\left(\mathrm{t}, J_{2,3}=J_{3,4}=9.8 \mathrm{~Hz}, 1 \mathrm{H}, 3-\mathrm{H}\right), 3.77\left(\mathrm{t}, J_{4,5}=J_{5,6}\right.$ $=9.3 \mathrm{~Hz}, 1 \mathrm{H}, 5-\mathrm{H}), 3.43\left(\mathrm{~s}, 3 \mathrm{H}, \mathrm{C}-1-\mathrm{OCH}_{3}\right), 3.28,3.26(2 \mathrm{~s}, 6 \mathrm{H}$, $\left.2 \mathrm{OCH}_{3} \mathrm{BDA}\right), 1.35,1.32\left(2 \mathrm{~s}, 6 \mathrm{H}, 2 \mathrm{CH}_{3} \mathrm{BDA}\right) \mathrm{ppm} .{ }^{13} \mathrm{C} \mathrm{NMR}$ $\left(90 \mathrm{MHz}, \mathrm{CDCl}_{3}\right): \delta=134.7,133.6,132.9$ (3 C, $3 \mathrm{C}_{\mathrm{q}}$ arom), 128.4, 128.0, 127.7, 126.4, 126.0, 125.7, 123.9 (7 C, arom), 101.6 (1 C, $\left.\mathrm{C}_{\mathrm{ac}}\right), 100.1,99.4$ (2 C, $2 \mathrm{C}_{\mathrm{q}}$ BDA), 98.7 (1 C, C-1), 79.0, 69.0, 66.5, 63.0 (4 C, skeleton carbons), 69.2 (1 C, C-6), $55.2\left(1 \mathrm{C}, \mathrm{C}-1-\mathrm{OCH}_{3}\right.$ ), 
48.0 (2 C, $\left.2 \mathrm{OCH}_{3} \mathrm{BDA}\right), 17.8,17.7$ (2 C, $\left.2 \mathrm{CH}_{3} \mathrm{BDA}\right)$ ppm. MS (MALDI-TOF): $\mathrm{m} / \mathrm{z}=469.33[\mathrm{M}+\mathrm{Na}]^{+} \cdot \mathrm{C}_{24} \mathrm{H}_{30} \mathrm{O}_{8}$ (446.19): calcd. C 64.56, H 6.77; found C 64.61, H 6.83.

Methyl 4,6-O-Benzylidene-2,3-O-(2',3'-dimethoxybutane-2', $3^{\prime}$-diyl)- $\alpha$-D-glucopyranoside (6): A mixture of compounds 3 and 4 $(5.00 \mathrm{~g}, 16.20 \mathrm{mmol})$, benzaldehyde dimethyl acetal $(2.67 \mathrm{~mL}$, $17.80 \mathrm{mmol})$, and $\mathrm{TsOH}(0.25$ equiv.) were treated according to general method C. The crude product was purified by silica gel chromatography ( $n$-hexane/acetone, 7:3) to give $\mathbf{6}(2.80 \mathrm{~g}, 44 \%)$ as a colourless syrup. $[\alpha]_{\mathrm{D}}^{24}=-58.9\left(c=0.09, \mathrm{CHCl}_{3}\right) . R_{\mathrm{f}}=0.49(n-$ hexane/acetone, 7:3). ${ }^{1} \mathrm{H}$ NMR (400 MHz, $\left.\mathrm{CDCl}_{3}\right): \delta=7.49-7.32$ (m, $5 \mathrm{H}$, arom), $5.52\left(\mathrm{~s}, 1 \mathrm{H}, \mathrm{H}_{\mathrm{ac}}\right), 4.75\left(\mathrm{~d}, J_{1,2}=3.5 \mathrm{~Hz}, 1 \mathrm{H}, 1-\right.$ H), 4.27-4.22 (m, $2 \mathrm{H}, 4-\mathrm{H}, 6-\mathrm{Ha}), 3.86\left(\mathrm{dd}, J_{1,2}=3.5, J_{2,3}=\right.$ $10.1 \mathrm{~Hz}, 2 \mathrm{H}, 2-\mathrm{H}, 6-\mathrm{Hb}), 3.76\left(\mathrm{t}, J_{2,3}=J_{3,4}=10.1 \mathrm{~Hz}, 1 \mathrm{H}, 3-\mathrm{H}\right)$, $3.69\left(\mathrm{t}, J_{4,5}=J_{5,6}=9.3 \mathrm{~Hz}, 1 \mathrm{H}, 5-\mathrm{H}\right), 3.42\left(\mathrm{~s}, 3 \mathrm{H}, \mathrm{C}-1-\mathrm{OCH}_{3}\right)$, $3.27,3.26\left(2 \mathrm{~s}, 6 \mathrm{H}, 2 \mathrm{OCH}_{3} \mathrm{BDA}\right), 1.35,1.31\left(2 \mathrm{~s}, 6 \mathrm{H}, 2 \mathrm{CH}_{3}\right.$ BDA) ppm. ${ }^{13} \mathrm{C}$ NMR $\left(100 \mathrm{MHz}, \mathrm{CDCl}_{3}\right): \delta=137.2\left(1 \mathrm{C}, \mathrm{C}_{\mathrm{q}}\right.$ arom), 128.7, 127.9, 126.0 (5 C, arom), 101.2 (1 C, $\left.\mathrm{C}_{\mathrm{ac}}\right), 99.9,99.2$ (2 C, $2 \mathrm{C}_{\mathrm{q}}$ BDA), 98.5 (1 C, C-1), 78.7, 68.8, 66.3, 63.2 (4 C, skeleton carbons), 68.9 (1 C, C-6), $54.9\left(1 \mathrm{C}, \mathrm{C}-1-\mathrm{OCH}_{3}\right), 47.8,47.7$ (2 $\mathrm{C}, 2 \mathrm{OCH}_{3}$ BDA), 17.6, $17.5\left(2 \mathrm{C}, 2 \mathrm{CH}_{3} \mathrm{BDA}\right)$ ppm. MS (MALDI-TOF): $\mathrm{m} / z=419.26\left[\mathrm{M}+\mathrm{Na}^{+} . \mathrm{C}_{20} \mathrm{H}_{28} \mathrm{O}_{8}\right.$ (396.18): calcd. C 60.59, H 7.12; found C 60.62, H 7.17.

Methyl 2,3-O-(2',3'-Dimethoxybutane-2',3'-diyl)-4,6-O-(4-methoxy)benzylidene- $\boldsymbol{\alpha}$-D-glucopyranoside (7): A mixture of compound 3 and $4(5.00 \mathrm{~g}, 16.20 \mathrm{mmol})$ was treated according to general method $\mathrm{C}$ using $p$-methoxybenzaldehyde dimethyl acetal $(3.0 \mathrm{~mL}$, $17.80 \mathrm{mmol}, 1.1$ equiv.) and $\mathrm{TsOH}(0.25$ equiv.). The crude product was purified by silica gel chromatography ( $n$-hexane/acetone, 7:3) to give $7(2.29 \mathrm{~g}, 33 \%)$ as a colourless syrup. $[a]_{\mathrm{D}}^{24}=-60.5(c=$ $\left.0.10, \mathrm{CHCl}_{3}\right) . \quad R_{\mathrm{f}}=0.38$ (n-hexane/acetone, 7:3). ${ }^{1} \mathrm{H} \quad \mathrm{NMR}$ $\left(400 \mathrm{MHz}, \mathrm{CDCl}_{3}\right): \delta=7.41-7.85(\mathrm{~m}, 4 \mathrm{H}, \operatorname{arom}), 5.48(\mathrm{~s}, 1 \mathrm{H}$, $\left.\mathrm{H}_{\mathrm{ac}}\right), 4.75\left(\mathrm{~d}, J_{1,2}=3.5 \mathrm{~Hz}, 1 \mathrm{H}, 1-\mathrm{H}\right), 4.26-4.21(\mathrm{~m}, 2 \mathrm{H}), 3.87-$ 3.80 (m, $2 \mathrm{H}), 3.77$ (s, $\left.3 \mathrm{H}, \mathrm{PMB}-\mathrm{OCH}_{3}\right), 3.75-3.65(\mathrm{~m}, 2 \mathrm{H}), 3.42$ (s, $\left.3 \mathrm{H}, \mathrm{C}-1-\mathrm{OCH}_{3}\right), 3.27,3.26\left(2 \mathrm{~s}, 6 \mathrm{H}, 2 \mathrm{OCH}_{3} \mathrm{BDA}\right), 1.35,1.31$ $\left(2 \mathrm{~s}, 6 \mathrm{H}, 2 \mathrm{CH}_{3} \mathrm{BDA}\right) \mathrm{ppm} .{ }^{13} \mathrm{C} \mathrm{NMR}\left(100 \mathrm{MHz}, \mathrm{CDCl}_{3}\right): \delta=$ 159.8, 129.7 (2 C, $2 \mathrm{C}_{\mathrm{q}}$ arom), 127.4, 113.3 (4 C, arom), 101.2 (1

$506 \mathrm{C}, \mathrm{C}_{\mathrm{ac}}$ ), 99.8, $99.2\left(2 \mathrm{C}, 2 \mathrm{C}_{\mathrm{q}}\right.$ BDA), 98.5 (1 C, C-1), 78.6, 68.8, 66.2, 63.2 (4 C, skeleton carbons), 68.8 (1 C, C-6), 55.0 (1 C, C-1$\left.\mathrm{OCH}_{3}\right), 54.9\left(1 \mathrm{C}, \mathrm{PMB}-\mathrm{OCH}_{3}\right), 47.8,47.7\left(2 \mathrm{C}, 2 \mathrm{OCH}_{3} \mathrm{BDA}\right)$, 17.5, $17.4\left(2 \mathrm{C}, 2 \mathrm{CH}_{3}\right.$ BDA) ppm. MS (MALDI-TOF): $\mathrm{m} / \mathrm{z}=$ $449.24[\mathrm{M}+\mathrm{Na}]^{+} \cdot \mathrm{C}_{21} \mathrm{H}_{30} \mathrm{O}_{9}$ (426.19): calcd. C 59.14, H 7.09;

511 found C $59.20, \mathrm{H} 7.13$.

Methyl 2,3-O-(2',3'-Dimethoxybutane-2',3'-diyl)-4-O-(2-naphthyl)methyl- $\alpha$-D-glucopyranoside (8): Compound 5 (3.00 g, $6.72 \mathrm{mmol})$ was converted into 8 by method $\mathrm{D}$ using anhydrous $\mathrm{CH}_{2} \mathrm{Cl}_{2}$ $(10.0 \mathrm{~mL})$, anhydrous $\mathrm{Et}_{2} \mathrm{O}(2 \times 5.0 \mathrm{~mL}), \mathrm{LiAlH}_{4}(1.14 \mathrm{~g}$,

$51630.24 \mathrm{mmol})$, and $\mathrm{AlCl}_{3}(1.34 \mathrm{~g}, 10.08 \mathrm{mmol})$ at room temperature. Purification by column chromatography on silica gel ( $n$-hexane/ acetone, 7:3) gave compound $\mathbf{8}(2.59 \mathrm{~g}, 86 \%)$ as a white foam. $[a]_{\mathrm{D}}^{24}=+5.1\left(c=0.04, \mathrm{CHCl}_{3}\right) . R_{\mathrm{f}}=0.31(n$-hexane/acetone, $7: 3)$. ${ }^{1} \mathrm{H}$ NMR (400 MHz, $\left.\mathrm{CDCl}_{3}\right): \delta=7.81-7.43(\mathrm{~m}, 7 \mathrm{H}$, arom), 5.12

$521\left(\mathrm{~d}, J_{\text {gem }}=11.4 \mathrm{~Hz}, 1 \mathrm{H}, \mathrm{NAP}-\mathrm{CH}_{2 \mathrm{a}}\right), 4.84\left(\mathrm{~d}, J_{\mathrm{gem}}=11.4 \mathrm{~Hz}, 1 \mathrm{H}\right.$, NAP-CH $\left.H_{2 \mathrm{~b}}\right), 4.73\left(\mathrm{~d}, J_{1,2}=3.5 \mathrm{~Hz}, 1 \mathrm{H}, 1-\mathrm{H}\right), 4.27(\mathrm{dd}, J=8.6, J$ $=10.0 \mathrm{~Hz}, 1 \mathrm{H}), 3.84-3.71(\mathrm{~m}, 5 \mathrm{H}), 3.39\left(\mathrm{~s}, 3 \mathrm{H}, \mathrm{C}-1-\mathrm{OCH}_{3}\right), 3.32$, $3.28\left(2 \mathrm{~s}, 6 \mathrm{H}, 2 \mathrm{OCH}_{3} \mathrm{BDA}\right), 2.13(\mathrm{~s}, 1 \mathrm{H}, \mathrm{OH}), 1.36,1.35(2 \mathrm{~s}, 6$ $\left.\mathrm{H}, 2 \mathrm{CH}_{3} \mathrm{BDA}\right) \mathrm{ppm} .{ }^{13} \mathrm{C}$ NMR $\left(100 \mathrm{MHz}, \mathrm{CDCl}_{3}\right): \delta=135.8$,

$526133.2,132.9$ (3 C, $3 \mathrm{C}_{\mathrm{q}}$ arom), 128.1, 127.9, 127.6, 126.6, 126.1, 126.0, 125.9 (7 C, arom), 99.9, 99.4 (2 C, $2 \mathrm{C}_{\mathrm{q}}$ BDA), 97.9 (1 C, C1), 75.0, 71.3, 70.4, 68.5 (4 C, skeleton carbons), 74.9 (1 C, NAP$\left.\mathrm{CH}_{2}\right), 61.9$ (1 C, C-6), $55.0\left(1 \mathrm{C}, \mathrm{C}-1-\mathrm{OCH}_{3}\right), 48.0,47.9$ (2 C, 2 $\left.\mathrm{OCH}_{3} \mathrm{BDA}\right), 18.0,17.7$ (2 C, $\left.2 \mathrm{CH}_{3} \mathrm{BDA}\right)$ ppm. MS (MALDI-
TOF): $m / z=471.09[\mathrm{M}+\mathrm{Na}]^{+} . \mathrm{C}_{24} \mathrm{H}_{32} \mathrm{O}_{8}$ (448.21): calcd. $\mathrm{C} 64.27$, H 7.19; found C 64.32, H 7.24.

Methyl 4-O-Benzyl-2,3-O-(2',3'-dimethoxybutane-2', $3^{\prime}$-diyl)- $\alpha$-Dglucopyranoside (9): Compound $6(396 \mathrm{mg}, 1.00 \mathrm{mmol})$ was converted to 9 by method $\mathrm{D}$ using anhydrous $\mathrm{CH}_{2} \mathrm{Cl}_{2}(3.0 \mathrm{~mL})$, anhydrous $\mathrm{Et}_{2} \mathrm{O}(2 \times 1.0 \mathrm{~mL}), \mathrm{LiAlH}_{4}(171 \mathrm{mg}, 4.50 \mathrm{mmol})$, and $\mathrm{AlCl}_{3}$ $(200 \mathrm{mg}, 1.50 \mathrm{mmol})$ at room temperature. Purification by column chromatography on silica gel ( $n$-hexane/acetone, 7:3) gave compound $9(294 \mathrm{mg}, 74 \%)$ as a colourless syrup. $[\alpha]_{\mathrm{D}}^{24}=-7.6(c=0.45$, $\left.\mathrm{CHCl}_{3}\right) . R_{\mathrm{f}}=0.32$ (n-hexane/acetone, 7:3). ${ }^{1} \mathrm{H}$ NMR $(400 \mathrm{MHz}$, $\left.\mathrm{CDCl}_{3}\right): \delta=7.34-7.25(\mathrm{~m}, 5 \mathrm{H}$, arom $), 4.97\left(\mathrm{~d}, J_{\text {gem }}=11.0 \mathrm{~Hz}, 1\right.$ $\left.\mathrm{H}, \mathrm{Ph}-\mathrm{CH}_{2 \mathrm{a}}\right), 4.73\left(\mathrm{~d}, J_{1,2}=3.3 \mathrm{~Hz}, 1 \mathrm{H}, 1-\mathrm{H}\right), 4.67\left(\mathrm{~d}, J_{\text {gem }}=\right.$ $\left.11.0 \mathrm{~Hz}, 1 \mathrm{H}, \mathrm{Ph}-\mathrm{CH}_{2 \mathrm{~b}}\right), 4.24\left(\mathrm{t}, J_{2,3}=J_{3,4}=9.4 \mathrm{~Hz}, 1 \mathrm{H}, 3-\mathrm{H}\right)$, 3.82-3.77 (m, 3 H, 2-H, 6-Ha,b), 3.75-3.65 (m, 2 H, 4-H, 5-H), 3.41 (s, $\left.3 \mathrm{H}, \mathrm{C}-1-\mathrm{OCH}_{3}\right), 3.30,3.28\left(2 \mathrm{~s}, 6 \mathrm{H}, 2 \mathrm{OCH}_{3} \mathrm{BDA}\right), 2.65$ (s, $1 \mathrm{H}, \mathrm{OH}), 1.36,1.35\left(2 \mathrm{~s}, 6 \mathrm{H}, 2 \mathrm{CH}_{3} \mathrm{BDA}\right) \mathrm{ppm} .{ }^{13} \mathrm{C} \mathrm{NMR}$ $\left(100 \mathrm{MHz}, \mathrm{CDCl}_{3}\right): \delta=138.1\left(1 \mathrm{C}, \mathrm{C}_{\mathrm{q}}\right.$ arom $), 128.1,127.7,127.5$ (5 C, arom), 99.6, 99.0 (2 C, $2 \mathrm{C}_{\mathrm{q}}$ BDA), 97.6 (1 C, C-1), 74.6 (1 $\mathrm{C}, \mathrm{Ph}-\mathrm{CH}_{2}$ ), 74.5, 71.2, 70.2, 68.1 (4 C, skeleton carbons), 61.4 (1 $\mathrm{C}, \mathrm{C}-6), 54.7$ (1 C, C-1-OCH 3$), 47.8,47.6\left(2 \mathrm{C}, 2 \mathrm{OCH}_{3} \mathrm{BDA}\right)$, 17.7, 17.4 ( $2 \mathrm{C}, 2 \mathrm{CH}_{3}$ BDA) ppm. MS (MALDI-TOF): $\mathrm{m} / \mathrm{z}=$ 421.27 [M + Na $]^{+} \cdot \mathrm{C}_{20} \mathrm{H}_{30} \mathrm{O}_{8}$ (398.19): calcd. C 60.29, H 7.59; found $\mathrm{C} 60.34, \mathrm{H} 7.63$.

Methyl 2,3-O-(2',3'-Dimethoxybutane-2', $\mathbf{3}^{\prime}$-diyl)-4-O-(4-methoxy)benzyl- $\alpha$-D-glucopyranoside (10): Compound 7 (426 mg, $1.00 \mathrm{mmol}$ ) was converted into $\mathbf{1 0}$ by method $\mathrm{D}$ using anhydrous $\mathrm{CH}_{2} \mathrm{Cl}_{2}$ $(3.0 \mathrm{~mL})$, anhydrous $\mathrm{Et}_{2} \mathrm{O}(2 \times 1.0 \mathrm{~mL}), \mathrm{LiAlH}_{4}(170 \mathrm{mg}$, $4.50 \mathrm{mmol})$, and $\mathrm{AlCl}_{3}(200 \mathrm{mg}, 1.50 \mathrm{mmol})$ at $0{ }^{\circ} \mathrm{C}$. Purification by column chromatography on silica gel ( $n$-hexane/EtOAc, 65:35) gave compound $\mathbf{1 0}(379 \mathrm{mg}, 89 \%)$ as a colourless syrup. $[\alpha]_{\mathrm{D}}^{24}=$ $-7.9\left(c=0.45, \mathrm{CHCl}_{3}\right) . R_{\mathrm{f}}=0.10\left(n\right.$-hexane/acetone, 65:35). ${ }^{1} \mathrm{H}$ NMR (360 MHz, $\left.\mathrm{CDCl}_{3}\right): \delta=7.28-6.84(\mathrm{~m}, 4 \mathrm{H}$, arom), 4.89-4.86 (m, $1 \mathrm{H}, \mathrm{PMB}-\mathrm{CH}_{2 \mathrm{a}}$ ), 4.70 (s, $\left.1 \mathrm{H}, 1-\mathrm{H}\right), 4.62-4.59$ (m, $1 \mathrm{H}$, PMB$\left.\mathrm{CH}_{2 \mathrm{~b}}\right), 4.22-4.18(\mathrm{~m}, 1 \mathrm{H}), 3.80-3.64(\mathrm{~m}, 8 \mathrm{H}, 5$ skeleton $\mathrm{H}, \mathrm{PMB}-$ $\left.\mathrm{OCH}_{3}\right), 3.37\left(\mathrm{~s}, 3 \mathrm{H}, \mathrm{C}-1-\mathrm{OCH}_{3}\right), 3.31,3.26\left(2 \mathrm{~s}, 6 \mathrm{H}, 2 \mathrm{OCH}_{3}\right.$ BDA), $2.69(\mathrm{~s}, 1 \mathrm{H}, \mathrm{OH}), 1.34\left(\mathrm{~s}, 6 \mathrm{H}, 2 \mathrm{CH}_{3} \mathrm{BDA}\right) \mathrm{ppm} \cdot{ }^{13} \mathrm{C}$ NMR (90 MHz, $\left.\mathrm{CDCl}_{3}\right): \delta=158.9,130.2\left(2 \mathrm{C}, 2 \mathrm{C}_{\mathrm{q}}\right.$ arom $), 129.2$, 113.4 (4 C, arom), 99.5, 98.9 (2 C, $2 \mathrm{C}_{\mathrm{q}}$ BDA), 97.5 (1 C, C-1), 74.0 (1 C, PMB- $\mathrm{CH}_{2}$ ), 74.2, 71.2, 70.1, 68.0 (skeleton carbons, $4 \mathrm{C}$ ), 61.2 (1 C, C-6), 54.7, 54.5 (2 C, PMB-OCH $\left.\mathrm{CH}_{3}, \mathrm{C}-1-\mathrm{OCH}_{3}\right), 47.5$, $47.3\left(2 \mathrm{C}, 2 \mathrm{OCH}_{3} \mathrm{BDA}\right), 17.5,17.3\left(2 \mathrm{C}, 2 \mathrm{CH}_{3} \mathrm{BDA}\right) \mathrm{ppm}$. MS (MALDI-TOF): $m / z=451.10[\mathrm{M}+\mathrm{Na}]^{+} \cdot \mathrm{C}_{21} \mathrm{H}_{32} \mathrm{O}_{9}$ (428.20): calcd. C 58.87, H 7.53; found C 58.90, H 7.57.

Methyl 2,3-O-(2',3'-Dimethoxybutane-2', $3^{\prime}$-diyl)-6-O-(2-naphthyl)methyl- $\alpha$-D-glucopyranoside (11a) and Methyl 2,3-O-(Butane-2',3'diyl)-6- $O$-(2-naphthyl)methyl-a-D-glucopyranoside (11b)

Reaction 1: Compound 5 (300 mg, $0.67 \mathrm{mmol}$ ) was converted into 11a and $11 \mathrm{~b}$ by method $\mathrm{E}$ using $\mathrm{BF}_{3} \cdot \mathrm{Et}_{2} \mathrm{O}$ (2.0 equiv.). The crude product was purified by silica gel chromatography ( $n$-hexane/acetone, $85: 15)$ to give 11a and 11b (150 mg, 50\%) as an inseparable mixture (11a/11b $=3: 2$ based on the NMR spectra) as a colourless syrup.

Reaction 2: Compound 5 (446 mg, $1.00 \mathrm{mmol}$ ) was converted into 11a by method F. Purification by column chromatography on silica gel ( $n$-hexane/acetone, $7: 3$ ) gave compound 11a (336 mg, 75\%) as a white foam.

Data for the Mixture of 11a and 11b: $R_{\mathrm{f}}=0.17$ ( $n$-hexane/acetone, 85:15). ${ }^{1} \mathrm{H}$ NMR (400 MHz, $\left.\mathrm{CDCl}_{3}\right): \delta=7.81-7.72(\mathrm{~m}, 10.5 \mathrm{H}$, arom), 4.81-4.68 (m, 4.5 H, 2 NAP-C $\left.H_{2}, 21-\mathrm{H}\right), 4.06-4.01(\mathrm{~m}, 1$ $\mathrm{H}), 3.83-3.73(\mathrm{~m}, 8 \mathrm{H}), 3.41\left(\mathrm{~s}, 4.5 \mathrm{H}, 2 \mathrm{C}-1-\mathrm{OCH}_{3}\right), 3.27,3.23(2$ s, $\left.6 \mathrm{H}, 2 \mathrm{OCH}_{3} \mathrm{BDA}\right), 2.95$ (s, $\left.0.5 \mathrm{H}, \mathrm{OH} 11 \mathrm{~b}\right), 2.85$ (s, $1 \mathrm{H}, \mathrm{OH}$ 
11a), 1.34, $1.31\left(2 \mathrm{~s}, 6 \mathrm{H}, 2 \mathrm{CH}_{3} \mathrm{BDA}\right), 1.15-1.11$ (m, $4 \mathrm{H}, 2 \mathrm{CH}_{3}$ butane-2', $3^{\prime}$-diyl) ppm. ${ }^{13} \mathrm{C}$ NMR $\left(100 \mathrm{MHz}, \mathrm{CDCl}_{3}\right): \delta=135.5$, 133.2, 133.0 (6 C, $6 \mathrm{C}_{\mathrm{q}}$ arom), 128.2, 127.8, 127.6, 126.4, 126.0, 125.8, 125.6 (14 C, arom), 99.8, 99.5 (2 C, $2 \mathrm{C}_{\mathrm{q}}$ BDA), 98.1 (1 C, C-1 11a), 97.9 (1 C, C-1 11b), 77.9, 77.0, 76.9, 76.3, 70.8, 70.6, 69.4, 69.1, 68.7, 68.1 (10 C, 8 skeleton carbons, $2 \mathrm{CH}$ butane-2',3'-diyl), 73.7 (2 C, 2 NAP- $\left.\mathrm{CH}_{2}\right), 69.5,69.4$ (2 C, 2 C-6), 55.1, 55.0 (2 C, 2 $\left.\mathrm{C}-1-\mathrm{OCH}_{3}\right), 47.9,47.8\left(2 \mathrm{C}, 2 \mathrm{OCH}_{3} \mathrm{BDA}\right), 17.8,17.6,17.2(4 \mathrm{C}$, $2 \mathrm{CH}_{3}$ BDA, $2 \mathrm{CH}_{3}$ butane-2', $3^{\prime}$-diyl) ppm. MS (MALDI-TOF):

$601 m / z=471.22[\mathrm{M}(\mathbf{1 1 a})+\mathrm{Na}]^{+}, 411.20[\mathrm{M}(\mathbf{1 1 b})+\mathrm{Na}]^{+}$.

Data for 11a: $[\alpha]_{\mathrm{D}}^{24}=-43.5\left(c=0.06, \mathrm{CHCl}_{3}\right) \cdot R_{\mathrm{f}}=0.45(n$-hexane/ acetone, 7:3). ${ }^{1} \mathrm{H}$ NMR $\left(400 \mathrm{MHz}, \mathrm{CDCl}_{3}\right): \delta=7.83-7.45(\mathrm{~m}, 7 \mathrm{H}$, arom), $4.80-4.7$ (m, $\left.3 \mathrm{H}, \mathrm{NAP}-\mathrm{CH}_{2}, 1-\mathrm{H}\right), 4.03(\mathrm{dd}, J=10.2, J=$ $8.9 \mathrm{~Hz}, 1 \mathrm{H}), 3.83-3.73(\mathrm{~m}, 5 \mathrm{H}), 3.42\left(\mathrm{~s}, 3 \mathrm{H}, \mathrm{C}-1-\mathrm{OCH}_{3}\right), 3.28$,

$6063.24\left(2 \mathrm{~s}, 6 \mathrm{H}, 2 \mathrm{OCH}_{3} \mathrm{BDA}\right), 2.66(\mathrm{~s}, 1 \mathrm{H}, \mathrm{OH}), 1.34,1.32(2 \mathrm{~s}, 6$ $\mathrm{H}, 2 \mathrm{CH}_{3}$ BDA) ppm. ${ }^{13} \mathrm{C}$ NMR $\left(100 \mathrm{MHz}, \mathrm{CDCl}_{3}\right): \delta=135.5$, 133.3, 133.1 (3 C, $\mathrm{C}_{\mathrm{q}}$ arom), 128.3, 127.9, 127.7, 126.5, 126.2, 125.9, 125.7 ( $7 \mathrm{C}$, arom), 99.9, 99.6 (2 C, $2 \mathrm{C}_{\mathrm{q}}$ BDA), 98.1 (1 C, C-1), 73.8 (1 C, NAP- $\mathrm{CH}_{2}$ ), 70.8, 69.4, 68.9, 68.2 (4 C, skeleton carbons), 69.5

611 (1 C, C-6), $55.2\left(1 \mathrm{C}, \mathrm{C}-1-\mathrm{OCH}_{3}\right), 48.0,47.9\left(2 \mathrm{C}, 2 \mathrm{OCH}_{3} \mathrm{BDA}\right)$, 17.8, 17.7 ( $2 \mathrm{C}, 2 \mathrm{CH}_{3}$ BDA) ppm. MS (MALDI-TOF): $\mathrm{m} / \mathrm{z}=$ 471.42 [M + Na $]^{+}$. $\mathrm{C}_{24} \mathrm{H}_{32} \mathrm{O}_{8}$ (448.21): calcd. C 64.27, $\mathrm{H}$ 7.19; found $\mathrm{C} 64.35, \mathrm{H} 7.25$. Methyl 6-O-Benzyl-2,3-O-(2',3'-dimethoxybutane-2', $3^{\prime}$-diyl)-a-D-
glucopyranoside (12a) and methyl 6-O-benzyl-2,3-O-(butane-2', $3^{\prime}-$ diyl)- $\alpha$-D-glucopyranoside (12b)

Reaction 1: Compound 6 (396 mg, $1.00 \mathrm{mmol})$ was converted into 12a and $\mathbf{1 2 b}$ by method $\mathrm{E}$ using $\mathrm{BF}_{3} \cdot \mathrm{Et}_{2} \mathrm{O}$ (1.0 equiv.). The crude product was purified by silica gel chromatography ( $n$-hexane/acet621 one, 7:3) to give 12a and $\mathbf{1 2 b}(199 \mathrm{mg}, 50 \%)$ as an inseparable mixture $(\mathbf{1 2} \mathbf{a} / \mathbf{1 2} \mathbf{b}=1: 1$ based on the NMR spectra) as a colourless syrup.

Reaction 2: $\mathrm{Et}_{3} \mathrm{SiH}(798 \mu \mathrm{L}, 5.00 \mathrm{mmol})$ and trifluoroacetic acid $(382 \mu \mathrm{L}, 5.00 \mathrm{mmol})$ were added to a solution of $6(396 \mathrm{mg}$,

$6261.00 \mathrm{mmol})$ in anhydrous $\mathrm{CH}_{2} \mathrm{Cl}_{2}(4.0 \mathrm{~mL})$ at $0{ }^{\circ} \mathrm{C}$. The reaction mixture was stirred at $0{ }^{\circ} \mathrm{C}$ for $10 \mathrm{~min}$. The mixture was diluted with EtOAc $(100 \mathrm{~mL})$, washed with saturated aqueous $\mathrm{NaHCO}_{3}$ $(2 \times 10.0 \mathrm{~mL})$ and $\mathrm{H}_{2} \mathrm{O}(2 \times 10.0 \mathrm{~mL})$, dried with $\mathrm{MgSO}_{4}$, and concentrated. The crude product was purified by column

631 chromatography on silica gel ( $n$-hexane/acetone, 7:3) to give 12a (194 $\mathrm{mg}, 49 \%$ ) as a colourless syrup.

Reaction 3: Compound 6 ( $260 \mathrm{mg}, 0.656 \mathrm{mmol}$ ) was converted into 12a by method F. Purification by column chromatography on silica gel ( $n$-hexane/acetone, 7:3) gave compound 12a (180 mg, 69\%) as a white foam, and compound $9(54 \mathrm{mg}, 20 \%)$ as a white foam.

Data for the Mixture of 12a and 12b: $R_{\mathrm{f}}=0.49$ ( $n$-hexane/acetone, 7:3). ${ }^{1} \mathrm{H}$ NMR (400 MHz, $\left.\mathrm{CDCl}_{3}\right): \delta=7.33-7.26$ (m, $10 \mathrm{H}$, arom), $4.80\left(\mathrm{~d}, J_{1,2}=3.5 \mathrm{~Hz}, 1 \mathrm{H}, 1-\mathrm{H}\right), 4.78\left(\mathrm{~d}, J_{1,2}=3.4 \mathrm{~Hz}, 1 \mathrm{H}, 1-\mathrm{H}\right)$, 4.63-4.54 (m, 4 H, 2 Ph-CH $), 4.05-4.00(\mathrm{~m}, 1 \mathrm{H}), 3.82-3.69(\mathrm{~m}$,

$64110 \mathrm{H}), 3.44-3.37(\mathrm{~m}, 3 \mathrm{H}), 3.41\left(\mathrm{~s}, 6 \mathrm{H}, 2 \mathrm{C}-1-\mathrm{OCH}_{3}\right), 3.30,3.23$ $\left(2 \mathrm{~s}, 6 \mathrm{H}, 2 \mathrm{OCH}_{3} \mathrm{BDA}\right), 3.15(\mathrm{~s}, 2 \mathrm{H}, \mathrm{OH}), 1.34,1.31(2 \mathrm{~s}, 6 \mathrm{H}, 2$ $\mathrm{CH}_{3}$ BDA), $1.16-1.12$ (m, $6 \mathrm{H}, 2 \mathrm{CH}_{3}$ butane-2', $3^{\prime}$-diyl) ppm. ${ }^{13} \mathrm{C}$ NMR (100 MHz, $\left.\mathrm{CDCl}_{3}\right): \delta=137.8\left(2 \mathrm{C}, 2 \mathrm{C}_{\mathrm{q}}\right.$ arom), 128.2, 127.5, 127.4 (10 C, arom), 99.6, 99.3 (2 C, $2 \mathrm{C}_{\mathrm{q}}$ BDA), 97.8, 97.7 (2 C, 2

$646 \mathrm{C}-1), 77.4,76.9,76.8,76.1,70.7,70.5,69.3,68.6,68.3,67.9(10 \mathrm{C}$, 8 skeleton carbons, $2 \mathrm{CH}$ butane-2', $3^{\prime}$-diyl), $73.4\left(2 \mathrm{C}, 2 \mathrm{Ph}-\mathrm{CH}_{2}\right)$, 69.2, 69.0 (2 C, 2 C-6), 55.0, $54.9\left(2 \mathrm{C}, 2 \mathrm{C}-1-\mathrm{OCH}_{3}\right), 47.8,47.7(2$ $\left.\mathrm{C}, 2 \mathrm{OCH}_{3} \mathrm{BDA}\right), 17.6,17.5,17.1$ (4 C, $2 \mathrm{CH}_{3} \mathrm{BDA}, 2 \mathrm{CH}_{3}$ butane$2^{\prime}, 3^{\prime}$-diyl) ppm. MS (MALDI-TOF): $m / z=421.26[\mathrm{M}(\mathbf{1 2 a})+$

$651 \mathrm{Na}]^{+}, 361.26[\mathrm{M}(\mathbf{1 2 b})+\mathrm{Na}]^{+}$.

Data for 12a: $[\alpha]_{\mathrm{D}}^{24}=-42.7\left(c=0.84, \mathrm{CHCl}_{3}\right) . R_{\mathrm{f}}=0.42(n$-hexane/ acetone, 7:3). ${ }^{1} \mathrm{H}$ NMR $\left(400 \mathrm{MHz}, \mathrm{CDCl}_{3}\right): \delta=7.33-7.26(\mathrm{~m}, 5 \mathrm{H}$, arom), $4.76\left(\mathrm{~d}, J_{1,2}=3.5 \mathrm{~Hz}, 1 \mathrm{H}, 1-\mathrm{H}\right), 4.58\left(\mathrm{q}, J_{\text {gem }}=12.0 \mathrm{~Hz}, 2\right.$ $\left.\mathrm{H}, \mathrm{Ph}-\mathrm{CH}_{2}\right), 4.02(\mathrm{dd}, J=8.6, J=10.1 \mathrm{~Hz}, 1 \mathrm{H}), 3.81-3.69(\mathrm{~m}, 5$ $\mathrm{H}), 3.41\left(\mathrm{~s}, 3 \mathrm{H}, \mathrm{C}-1-\mathrm{OCH}_{3}\right), 3.27,3.23\left(2 \mathrm{~s}, 6 \mathrm{H}, 2 \mathrm{OCH}_{3} \mathrm{BDA}\right)$, $2.98(\mathrm{~s}, 1 \mathrm{H}, \mathrm{OH}), 1.34,1.31\left(2 \mathrm{~s}, 6 \mathrm{H}, 2 \mathrm{CH}_{3} \mathrm{BDA}\right) \mathrm{ppm} .{ }^{13} \mathrm{C}$ NMR (100 MHz, $\left.\mathrm{CDCl}_{3}\right): \delta=137.9\left(1 \mathrm{C}, \mathrm{C}_{\mathrm{q}}\right.$ arom), 128.2, 127.5, 127.4 (5 C, arom), 99.7, 99.3 (2 C, $2 \mathrm{C}_{\mathrm{q}}$ BDA), 97.9 (1 C, C-1), 73.4 (1 C, Ph- $\mathrm{CH}_{2}$ ), 70.7, 69.3, 68.5, 68.0 (4 C, skeleton carbons), 69.2 (1 C, C-6), 54.9 (1 C, C-1-OCH$\left.{ }_{3}\right), 47.8,47.7$ (2 C, $\left.2 \mathrm{OCH}_{3} \mathrm{BDA}\right)$, 17.6, $17.5\left(2 \mathrm{C}, 2 \mathrm{CH}_{3}\right.$ BDA) ppm. MS (MALDI-TOF): $\mathrm{m} / \mathrm{z}=$ 421.22 [M + Na $]^{+}$. $\mathrm{C}_{20} \mathrm{H}_{30} \mathrm{O}_{8}$ (398.19): calcd. C 60.29, H 7.59; found $\mathrm{C} 60.33, \mathrm{H} 7.64$.

Methyl 2,3-O-(2',3'-Dimethoxybutane-2', 3'-diyl)-6-O-(4-methoxy)benzyl- $\alpha$-D-glucopyranoside (13)

Reaction 1: Compound 7 (200 mg, $0.47 \mathrm{mmol}$ ) was converted into 13 by method $\mathrm{E}$ using $\mathrm{BF}_{3} \cdot \mathrm{Et}_{2} \mathrm{O}$ (1.0 equiv.). The crude product was purified by silica gel chromatography ( $n$-hexane/acetone, 7:3) to give $\mathbf{1 3}$ (30 mg, 15\%) as a colourless syrup. Compound $\mathbf{3}$ (34 mg, $17 \%$ ) was also isolated from the reaction mixture as a white foam.

Reaction 2: Compound 7 (425 mg, $1.00 \mathrm{mmol})$ was converted into 13 by method F. Purification by column chromatography on silica gel ( $n$-hexane/acetone, 7:3) gave compound $\mathbf{1 3}(101 \mathrm{mg}, 24 \%)$ as a white foam, and compound $\mathbf{1 0}(81 \mathrm{mg}, 20 \%)$ as a white foam. $[\alpha]_{\mathrm{D}}^{24}=-43.3\left(c=0.33, \mathrm{CHCl}_{3}\right) \cdot R_{\mathrm{f}}=0.26(n$-hexane/acetone, $7: 3)$. ${ }^{1} \mathrm{H}$ NMR $\left(400 \mathrm{MHz}, \mathrm{CDCl}_{3}\right): \delta=7.27-6.86(\mathrm{~m}, 4 \mathrm{H}$, arom), 4.77 $\left(\mathrm{d}, J_{1,2}=3.5 \mathrm{~Hz}, 1 \mathrm{H}, 1-\mathrm{H}\right), 4.53\left(\mathrm{q}, J_{\text {gem }}=11.7 \mathrm{~Hz}, 2 \mathrm{H}\right.$, PMB$\left.\mathrm{CH}_{2}\right), 4.02(\mathrm{dd}, J=8.8, J=10.2 \mathrm{~Hz}, 1 \mathrm{H}), 3.80$ (s, $3 \mathrm{H}$, PMB$\left.\mathrm{OCH}_{3}\right), 3.79-3.66(\mathrm{~m}, 5 \mathrm{H}), 3.43\left(\mathrm{~s}, 3 \mathrm{H}, \mathrm{C}-1-\mathrm{OCH}_{3}\right), 3.29,3.25(2$ s, $\left.6 \mathrm{H}, 2 \mathrm{OCH}_{3} \mathrm{BDA}\right), 2.56(\mathrm{~s}, 1 \mathrm{H}, \mathrm{OH}), 1.34,1.32(2 \mathrm{~s}, 6 \mathrm{H}, 2$ $\mathrm{CH}_{3}$ BDA) ppm. ${ }^{13} \mathrm{C}$ NMR (100 MHz, $\left.\mathrm{CDCl}_{3}\right): \delta=159.3,130.1$ (2 C, $2 \mathrm{C}_{\mathrm{q}}$ arom), 129.4, 113.9 (4 C, arom), 99.9, 99.5 (2 C, $2 \mathrm{C}_{\mathrm{q}}$ BDA), 98.1 (1 C, C-1), 73.4 (1 C, PMB- $\mathrm{CH}_{2}$ ), 70.6, 69.4, 69.2, 68.2 (4 C, skeleton carbons), 69.3 (1 C, C-6), 55.4, 55.2 (2 C, PMB$\left.\mathrm{OCH}_{3}, \mathrm{C}-1-\mathrm{OCH}_{3}\right), 48.1,47.9\left(2 \mathrm{C}, 2 \mathrm{OCH}_{3} \mathrm{BDA}\right), 17.9,17.8$ (2 C, $2 \mathrm{CH}_{3}$ BDA) ppm. MS (MALDI-TOF): $\mathrm{m} / z=451.20[\mathrm{M}+$ $\mathrm{Na}^{+} . \mathrm{C}_{21} \mathrm{H}_{32} \mathrm{O}_{9}$ (428.20): calcd. C 58.87, H 7.53; found C 58.90, H 7.55 .

Methyl 2,3-O-(2',3'-Dimethoxybutane-2', $\mathbf{3}^{\prime}$-diyl)- $\beta$-D-glucopyrano-

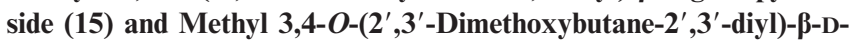
glucopyranoside (16): Compound $\mathbf{1 4}(2.00 \mathrm{~g}, 10.3 \mathrm{mmol})$ was converted into a mixture of $\mathbf{1 5}$ and $\mathbf{1 6}$ by method B. Purification by column chromatography on silica gel ( $n$-hexane/acetone, 6:4) gave compounds $\mathbf{1 5}$ and $\mathbf{1 6}(2.70 \mathrm{~g}, 85 \%$, inseparable mixture $)$ as a white foam. $R_{\mathrm{f}}=0.28\left(n\right.$-hexane/acetone, 6:4). ${ }^{1} \mathrm{H}$ NMR $(400 \mathrm{MHz}$, $\left.\mathrm{CDCl}_{3}\right): \delta=4.47\left(\mathrm{~d}, J_{1,2}=7.9 \mathrm{~Hz}, 1 \mathrm{H}, 1-\mathrm{H}\right), 4.29\left(\mathrm{~d}, J_{1,2}=7.5 \mathrm{~Hz}\right.$, $0.7 \mathrm{H}, 1-\mathrm{H}), 3.91-3.68(\mathrm{~m}, 7.3 \mathrm{H}), 3.57,3.54(2 \mathrm{~s}, 5.1 \mathrm{H}, 2 \mathrm{C}-1-$ $\left.\mathrm{OCH}_{3}\right), 3.52-3.37(\mathrm{~m}, 4.6 \mathrm{H}), 3.31,3.30,3.28,3.26(4 \mathrm{~s}, 10.2 \mathrm{H}, 4$ $\left.\mathrm{OCH}_{3} \mathrm{BDA}\right), 2.73(\mathrm{~s}, 0.7 \mathrm{H}, \mathrm{OH}), 2.37(\mathrm{~s}, 1 \mathrm{H}, \mathrm{OH}), 1.34,1.33$, $1.30\left(3 \mathrm{~s}, 10.2 \mathrm{H}, 4 \mathrm{CH}_{3} \mathrm{BDA}\right) \mathrm{ppm} .{ }^{13} \mathrm{C} \mathrm{NMR}\left(100 \mathrm{MHz}, \mathrm{CDCl}_{3}\right)$ : $\delta=104.6,101.7$ (2 C, 2 C-1), 99.8, 99.7, 99.6, 99.5 (4 C, 4 C $\mathrm{q}_{\mathrm{q}}$ BDA), 76.3, 74.1, 72.6, 71.8, 71.2, 69.3, 67.5, 65.7 (8 C, skeleton carbons), 62.1, 61.2 (2 C, $2 \mathrm{C}-6), 57.6,57.1\left(2 \mathrm{C}, 2 \mathrm{OCH}_{3}\right), 48.2,48.1,48.0$, 47.9 (4 C, $\left.4 \mathrm{OCH}_{3} \mathrm{BDA}\right), 17.7,17.6$ (4 C, $\left.4 \mathrm{CH}_{3} \mathrm{BDA}\right)$ ppm. MS (MALDI-TOF): $m / z=331.22\left[\mathrm{M}+\mathrm{Na}^{+} . \mathrm{C}_{13} \mathrm{H}_{24} \mathrm{O}_{8}\right.$ (308.15): calcd. C 50.64, H 7.85; found C 50.71, H 7.93 .

Methyl 4,6- $O$-Benzylidene-2,3- $O$-(2', $3^{\prime}$-dimethoxybutane-2', $3^{\prime}$-diyl)$\beta$-D-glucopyranoside (17): A mixture of compounds 15 and 16 (600 mg, $1.95 \mathrm{mmol}$ ), benzaldehyde dimethyl acetal (444 mg, $2.92 \mathrm{mmol}, 1.5$ equiv.), and $\mathrm{TsOH}(45 \mathrm{mg}, 0.237 \mathrm{mmol}, 0.12$ equiv.) were treated according to general method $\mathrm{C}$. The crude product was purified by silica gel chromatography ( $n$-hexane/acetone, 8:2) to give 17 (417 mg, 54\%) as white crystals, m.p. $269-273{ }^{\circ} \mathrm{C}$. $[\alpha]_{\mathrm{D}}^{24}=-190.1\left(c=0.08, \mathrm{CHCl}_{3}\right) . R_{\mathrm{f}}=0.41$ ( $n$-hexane/acetone, 8:2). 
${ }^{1} \mathrm{H}$ NMR (400 MHz, $\left.\mathrm{CDCl}_{3}\right): \delta=7.49-7.34(\mathrm{~m}, 5 \mathrm{H}$, arom), 5.53 $\left(\mathrm{s}, 1 \mathrm{H}, \mathrm{H}_{\mathrm{ac}}\right), 4.52\left(\mathrm{~d}, J_{1,2}=8.0 \mathrm{~Hz}, 1 \mathrm{H}, 1-\mathrm{H}\right), 4.32\left(\mathrm{dd}, J_{5,6}=4.8\right.$, $\left.J_{\text {gem }}=10.4 \mathrm{~Hz}, 1 \mathrm{H}, 6-\mathrm{Ha}\right), 4.00\left(\mathrm{t}, J_{2,3}=J_{3,4}=9.8 \mathrm{~Hz}, 1 \mathrm{H}, 3-\right.$ $\mathrm{H}), 3.81\left(\mathrm{t}, J_{5,6}=J_{\text {gem }}=10.3 \mathrm{~Hz}, 1 \mathrm{H}, 6-\mathrm{Hb}\right), 3.70\left(\mathrm{t}, J_{4,5}=J_{3,4}=\right.$ $9.4 \mathrm{~Hz}, 1 \mathrm{H}, 4-\mathrm{H}), 3.62\left(\mathrm{dd}, 1 \mathrm{H}, J_{2,3}=9.7, J_{1,2}=8.1 \mathrm{~Hz}, 2-\mathrm{H}\right)$, $7213.56\left(\mathrm{~s}, 3 \mathrm{H}, \mathrm{C}-1-\mathrm{OCH}_{3}\right), 3.50-3.44(\mathrm{~m}, 1 \mathrm{H}, 5-\mathrm{H}), 3.30,3.29(2 \mathrm{~s}$, $\left.6 \mathrm{H}, 2 \mathrm{OCH}_{3} \mathrm{BDA}\right), 1.34,1.33\left(2 \mathrm{~s}, 6 \mathrm{H}, 2 \mathrm{CH}_{3} \mathrm{BDA}\right) \mathrm{ppm} .{ }^{13} \mathrm{C}$ $\operatorname{NMR}\left(100 \mathrm{MHz}, \mathrm{CDCl}_{3}\right): \delta=137.3\left(1 \mathrm{C}, C_{\mathrm{q}}\right.$ arom $), 129.0,128.3$, 126.3 (5 C, arom.), 102.2 (1 C, $\mathrm{C}_{\mathrm{ac}}$ ), 101.3 (1 C, C-1), 99.8, 99.5 (2 C, $2 \mathrm{C}_{\mathrm{q}}$ BDA), 77.9, 70.4, 69.5, 67.6 (4 C, skeleton carbons), 68.9

726 (1 C, C-6), $57.4\left(1 \mathrm{C}, \mathrm{C}-1-\mathrm{OCH}_{3}\right), 48.2,48.1\left(2 \mathrm{C}, 2 \mathrm{OCH}_{3} \mathrm{BDA}\right)$, 17.7, 17.6 ( $2 \mathrm{C}, 2 \mathrm{CH}_{3}$ BDA) ppm. MS (MALDI-TOF): $\mathrm{m} / \mathrm{z}=$ $419.19\left[\mathrm{M}+\mathrm{Na}^{+} . \mathrm{C}_{20} \mathrm{H}_{28} \mathrm{O}_{8}\right.$ (396.18): calcd. C 60.59, $\mathrm{H}$ 7.12; found C $60.69, \mathrm{H} 7.20$.

Methyl 4- $O$-Benzyl-2,3-O-(2',3'-dimethoxybutane-2', $3^{\prime}$-diyl)- $\beta$-Dglucopyranoside (18): Compound 17 (396 mg, $1.00 \mathrm{mmol})$ was converted into 18 by method $\mathrm{D}$ using anhydrous $\mathrm{CH}_{2} \mathrm{Cl}_{2}(9.0 \mathrm{~mL})$, anhydrous $\mathrm{Et}_{2} \mathrm{O}(2 \times 3.0 \mathrm{~mL}), \mathrm{LiAlH}_{4}(171 \mathrm{mg}, 4.50 \mathrm{mmol})$, and $\mathrm{AlCl}_{3}(600 \mathrm{mg}, 4.50 \mathrm{mmol})$. Purification by column chromatography on silica gel ( $n$-hexane/acetone, 7:3) gave compound $\mathbf{1 8}$ $(330 \mathrm{~g}, 83 \%)$ as a white foam. $[a]_{\mathrm{D}}^{24}=-105.4\left(c=1.08, \mathrm{CHCl}_{3}\right) . R_{\mathrm{f}}$ $=0.42\left(n\right.$-hexane/acetone, 7:3). ${ }^{1} \mathrm{H}$ NMR $\left(400 \mathrm{MHz}, \mathrm{CDCl}_{3}\right): \delta=$ 7.34-7.28 (m, $5 \mathrm{H}$, arom), $4.96\left(\mathrm{~d}, J_{\text {gem }}=11.0 \mathrm{~Hz}, 1 \mathrm{H}, \mathrm{Ph}-\mathrm{CH}_{2 \mathrm{a}}\right)$, $4.65\left(\mathrm{~d}, J_{\text {gem }}=11.0 \mathrm{~Hz}, 1 \mathrm{H}, \mathrm{Ph}-\mathrm{CH}_{2 \mathrm{~b}}\right), 4.44\left(\mathrm{~d}, J_{1,2}=7.9 \mathrm{~Hz}, 1\right.$ $\mathrm{H}, 1-\mathrm{H}), 3.91\left(\mathrm{t}, J_{2,3}=J_{3,4}=9.8 \mathrm{~Hz}, 1 \mathrm{H}, 3-\mathrm{H}\right), 3.85\left(\mathrm{~d}, J_{\text {gem }}=\right.$ $11.9 \mathrm{~Hz}, 1 \mathrm{H}, 6-\mathrm{Ha}), 3.72\left(\mathrm{dd}, J_{5,6}=4.2, J_{\mathrm{gem}}=11.9 \mathrm{~Hz}, 1 \mathrm{H}, 6-\right.$ $\mathrm{Hb}), 3.66\left(\mathrm{t}, J_{4,5}=J_{3,4}=9.3 \mathrm{~Hz}, 1 \mathrm{H}, 4-\mathrm{H}\right), 3.55-3.52(\mathrm{~m}, 1 \mathrm{H}, 2-$ $\mathrm{H}), 3.51\left(\mathrm{~s}, 3 \mathrm{H}, \mathrm{C}-1-\mathrm{OCH}_{3}\right), 3.41-3.39(\mathrm{~m}, 1 \mathrm{H}, 5-\mathrm{H}), 3.31,3.30$ $\left(2 \mathrm{~s}, 6 \mathrm{H}, 2 \mathrm{OCH}_{3} \mathrm{BDA}\right), 2.26(\mathrm{~s}, 1 \mathrm{H}, \mathrm{OH}), 1.36,1.34(2 \mathrm{~s}, 6 \mathrm{H}, 2$ $\left.\mathrm{CH}_{3} \mathrm{BDA}\right) \mathrm{ppm} .{ }^{13} \mathrm{C}$ NMR $\left(100 \mathrm{MHz}, \mathrm{CDCl}_{3}\right): \delta=138.2\left(1 \mathrm{C}, \mathrm{C}_{\mathrm{q}}\right.$ arom), 128.4, 128.1, 127.8 (5 C, arom), 101.4 (1 C, C-1), 99.4, 99.3 (2 C, $\left.2 \mathrm{C}_{\mathrm{q}} \mathrm{BDA}\right), 77.8(1 \mathrm{C}, \mathrm{C}-5), 74.9\left(1 \mathrm{C}, \mathrm{Ph}-\mathrm{CH}_{2}\right), 74.5(1 \mathrm{C}$, C-4), 73.5 (1 C, C-3), 69.5 (1 C, C-2), 61.8 (1 C, C-6), 56.9 (1 C, $\left.\mathrm{C}-1-\mathrm{OCH}_{3}\right), 47.9,47.8\left(2 \mathrm{C}, 2 \mathrm{OCH}_{3} \mathrm{BDA}\right), 17.8,17.5(2 \mathrm{C}, 2$ $\mathrm{CH}_{3}$ BDA) ppm. MS (MALDI-TOF): $m / z=421.22\left[\mathrm{M}+\mathrm{Na}^{+}\right.$.

$751 \mathrm{C}_{20} \mathrm{H}_{30} \mathrm{O}_{8}$ (398.19): calcd. C 60.29, H 7.59; found C 60.36, H 7.71.

Methyl 6-O-Benzyl-2,3-O-(2',3'-dimethoxybutane-2', $3^{\prime}$-diyl)- $\beta$-Dglucopyranoside (19a) and Methyl 6-O-Benzyl-2,3-O-(butane-2',3'diyl)-p-D-glucopyranoside (19b)

Reaction 1: Compound $17(150 \mathrm{mg}, 0.378 \mathrm{mmol})$ was converted 756 into $19 \mathrm{a}$ and $19 \mathrm{~b}$ by method $\mathrm{E}$ using $\mathrm{BF}_{3} \cdot \mathrm{Et}_{2} \mathrm{O}$ (2.0 equiv.) and molecular sieves ( $4 \AA ; 0.5 \mathrm{~g}$ ). The crude product was purified by silica gel chromatography ( $n$-hexane/acetone, $7: 3)$ to give 19a and 19b $(71 \mathrm{mg}, 47 \%)$ as an inseparable mixture $(\mathbf{1 9 a} \mathbf{a} / \mathbf{1 9 b}=1: 1$ based on the NMR spectra) as a colourless syrup.

761 Reaction 2: Compound 17 (160 mg, $0.403 \mathrm{mmol})$ was converted into $19 \mathrm{a}$ and $19 \mathrm{~b}$ by method $\mathrm{E}$ using $\mathrm{BF}_{3} \cdot \mathrm{Et}_{2} \mathrm{O}$ (1.0 equiv.) and molecular sieves $(4 \AA ; 0.5 \mathrm{~g})$. The crude product was purified by silica gel chromatography ( $n$-hexane/acetone, 7:3) to give 19a and 19b $(90 \mathrm{mg}, 56 \%)$ as an inseparable mixture $(\mathbf{1 9 a} / \mathbf{1 9 b}=1: 0.8$ based on the NMR spectra) as a colourless syrup.

Reaction 3: Compound 17 (160 mg, $0.403 \mathrm{mmol})$ was converted into 19a by method F. Purification by column chromatography on silica gel ( $n$-hexane/acetone, 7:3) gave compound 19a (136 mg, $85 \%)$ as a white foam.

771 Data for the mixture of 19a and 19b: $R_{\mathrm{f}}=0.50$ ( $n$-hexane/acetone, 6:4). ${ }^{1} \mathrm{H}$ NMR (400 MHz, $\mathrm{CDCl}_{3}$ ): $\delta=7.34-7.27(\mathrm{~m}, 10 \mathrm{H}$, arom), 4.63-4.56 (m, $\left.4 \mathrm{H}, 2 \mathrm{Ph}-\mathrm{CH}_{2}\right), 4.43\left(\mathrm{~d}, J_{1,2}=7.9 \mathrm{~Hz}, 1 \mathrm{H}, 1-\mathrm{H}\right)$, $4.36\left(\mathrm{~d}, J_{1,2}=7.7 \mathrm{~Hz}, 1 \mathrm{H}, 1-\mathrm{H}\right), 3.80-3.63(\mathrm{~m}, 9 \mathrm{H}), 3.55,3.53(2$ s, $\left.6 \mathrm{H}, 2 \mathrm{C}-1-\mathrm{OCH}_{3}\right), 3.42-3.31(\mathrm{~m}, 7 \mathrm{H}), 3.28,3.27(2 \mathrm{~s}, 6 \mathrm{H}, 2$ butane-2', $3^{\prime}$-diyl) ppm. ${ }^{13} \mathrm{C}$ NMR $\left(100 \mathrm{MHz}, \mathrm{CDCl}_{3}\right): \delta=137.9(2$ $\mathrm{C}, 2 \mathrm{C}_{\mathrm{q}}$ arom), 128.5, 127.8, 127.7 (10 C, arom), 101.5, 101.4 (2 C, 2 C-1), 99.6, 99.5 (2 C, $2 \mathrm{C}_{\mathrm{q}}$ BDA), 80.6, 77.6, 77.3, 76.8, 75.1, $74.9,72.5,69.4,69.2,69.1$ (10 C, 8 skeleton carbons, $2 \mathrm{CH}$ butane$2^{\prime}, 3^{\prime}$-diyl), 73.7 (2 C, 2 Ph- $\mathrm{CH}_{2}$ ), 70.2 (2 C, 2 C-6), 56.9 (2 C, 2 C1- $\left.\mathrm{OCH}_{3}\right), 48.1,47.9\left(2 \mathrm{C}, 2 \mathrm{OCH}_{3} \mathrm{BDA}\right), 17.7,17.6,17.3(4 \mathrm{C}, 2$ $\mathrm{CH}_{3}$ BDA, $2 \mathrm{CH}_{3}$ butane-2', $3^{\prime}$-diyl) ppm. MS (MALDI-TOF): $\mathrm{m} / \mathrm{z}$ $=421.21[\mathrm{M}(\mathbf{1 9 a})+\mathrm{Na}]^{+}, 361.18[\mathrm{M}(\mathbf{1 9 b})+\mathrm{Na}]^{+}$

Data for 19a: $[\alpha]_{\mathrm{D}}^{24}=-126.9\left(c=0.45, \mathrm{CHCl}_{3}\right) . R_{\mathrm{f}}=0.40(n$-hexane/ acetone, 7:3). ${ }^{1} \mathrm{H}$ NMR (400 MHz, $\left.\mathrm{CDCl}_{3}\right): \delta=7.34-7.27(\mathrm{~m}, 5 \mathrm{H}$, arom), $4.60\left(\mathrm{~d}, J_{\text {gem }}=3.5 \mathrm{~Hz}, 2 \mathrm{H}, \mathrm{Ph}-\mathrm{CH}_{2}\right), 4.43\left(\mathrm{~d}, J_{1,2}=7.9 \mathrm{~Hz}\right.$, $1 \mathrm{H}, 1-\mathrm{H}), 3.77-3.69(\mathrm{~m}, 5 \mathrm{H}), 3.51(\mathrm{~s}, 4 \mathrm{H}, 1$ skeleton $\mathrm{H}, \mathrm{C}-1-$ $\left.\mathrm{OCH}_{3}\right), 3.29,3.27\left(2 \mathrm{~s}, 6 \mathrm{H}, 2 \mathrm{OCH}_{3} \mathrm{BDA}\right), 2.97(\mathrm{~s}, 1 \mathrm{H}, \mathrm{OH}), 1.33$ (s, $\left.6 \mathrm{H}, 2 \mathrm{CH}_{3} \mathrm{BDA}\right) \mathrm{ppm} .{ }^{13} \mathrm{C} \mathrm{NMR}\left(100 \mathrm{MHz}, \mathrm{CDCl}_{3}\right): \delta=137.9$ (1 C, $\mathrm{C}_{\mathrm{q}}$ arom), 128.4, 127.7, 127.6 (5 C, arom), 101.4 (1 C, C-1), 99.5, 99.4 ( 2 C, $2 \mathrm{C}_{\mathrm{q}}$ BDA), 75.1, 72.5, 69.2, 69.0 (4 C, skeleton carbons), 73.7 ( $\left.1 \mathrm{C}, \mathrm{Ph}-\mathrm{CH}_{2}\right), 70.1$ (1 C, C-6), 56.8 (1 C, C-1$\left.\mathrm{OCH}_{3}\right), 48.0,47.9\left(2 \mathrm{C}, 2 \mathrm{OCH}_{3} \mathrm{BDA}\right), 17.7,17.2\left(2 \mathrm{C}, 2 \mathrm{CH}_{3}\right.$ BDA) ppm. MS (MALDI-TOF): $m / z=421.27\left[\mathrm{M}+\mathrm{Na}^{+}\right.$ $\mathrm{C}_{20} \mathrm{H}_{30} \mathrm{O}_{8}$ (398.19): calcd. C 60.29, H 7.59; found C 60.33, H 7.68.

Phenyl 2,3-O-(2', $3^{\prime}$-Dimethoxybutane-2', $3^{\prime}$-diyl)-1-thio- $\beta$-D-glucopyranoside (21) and Phenyl 3,4-O-(2',3'-Dimethoxybutane-2', $3^{\prime}$ diyl)-1-thio- $\boldsymbol{\beta}$-D-glucopyranoside (22): $:^{[3,30]}$ Compound 20 (2.72 g, $10.00 \mathrm{mmol}$ ) was converted into $\mathbf{2 1}$ and $\mathbf{2 2}$ by method A. Purification by column chromatography on silica gel $\left(\mathrm{CH}_{2} \mathrm{Cl}_{2} / \mathrm{CH}_{3} \mathrm{OH}\right.$, 95:5) gave compound $21(1.50 \mathrm{~g}, 39 \%)$ as a white foam, and compound $22(2.26 \mathrm{~g}, 59 \%)$ as a white foam.

Data for 21: $[\alpha]_{\mathrm{D}}^{24}=-142.5\left(c=0.33, \mathrm{CHCl}_{3}\right)$; ref. ${ }^{[30]}[\alpha]_{\mathrm{D}}^{25}=-156.9$ $(c=1.0) . R_{\mathrm{f}}=0.40\left(\mathrm{CH}_{2} \mathrm{Cl}_{2} / \mathrm{CH}_{3} \mathrm{OH}, 95: 5\right) .{ }^{1} \mathrm{H}$ NMR $(400 \mathrm{MHz}$, $\left.\mathrm{CDCl}_{3}\right): \delta=7.50-7.23(\mathrm{~m}, 5 \mathrm{H}$, arom $), 4.83\left(\mathrm{~d}, J_{1,2}=9.7 \mathrm{~Hz}, 1 \mathrm{H}\right.$, 1-H), 3.90-3.87 (m, $1 \mathrm{H}, 6-\mathrm{Ha}), 3.82-3.75$ (m, $2 \mathrm{H}, 6-\mathrm{Hb}, 4-\mathrm{H})$, $3.74\left(\mathrm{t}, J_{2,3}=J_{3,4}=9.5 \mathrm{~Hz}, 1 \mathrm{H}, 3-\mathrm{H}\right), 3.60\left(\mathrm{t}, J_{1,2}=J_{2,3}=9.7 \mathrm{~Hz}\right.$, $1 \mathrm{H}, 2-\mathrm{H}), 3.44-3.39(\mathrm{~m}, 1 \mathrm{H}, 5-\mathrm{H}), 3.28,3.22\left(2 \mathrm{~s}, 7 \mathrm{H}, 2 \mathrm{OCH}_{3}\right.$ BDA, C-4-OH), $2.55\left(\mathrm{t}, J_{6 \mathrm{a}, \mathrm{b}, \mathrm{OH}}=6.5 \mathrm{~Hz}, 1 \mathrm{H}, \mathrm{C}-6-\mathrm{O} H\right), 1.33,1.32$ $\left(2 \mathrm{~s}, 6 \mathrm{H}, 2 \mathrm{CH}_{3} \mathrm{BDA}\right) \mathrm{ppm} .{ }^{13} \mathrm{C}$ NMR $\left(100 \mathrm{MHz}, \mathrm{CDCl}_{3}\right): \delta=$ 133.4 (1 C, $\mathrm{C}_{\mathrm{q}}$ arom), 131.5, 129.0, 127.5 (5 C, arom), 100.2, 99.8 (2 C, $2 \mathrm{C}_{\mathrm{q}}$ BDA), 85.3 (1 C, C-1), 80.1 (1 C, C-5), 74.4 (1 C, C-3), 68.2 (1 C, C-2), 67.6 (1 C, C-4), 62.4 (1 C, C-6), 48.3, 48.0 (2 C, 2 $\left.\mathrm{OCH}_{3} \mathrm{BDA}\right), 17.7,17.6\left(2 \mathrm{C}, 2 \mathrm{CH}_{3} \mathrm{BDA}\right) \mathrm{ppm}$. MS (MALDITOF) $m / z=409.17[\mathrm{M}+\mathrm{Na}]^{+} . \mathrm{C}_{18} \mathrm{H}_{26} \mathrm{O}_{7} \mathrm{~S}$ (386.46): calcd. C 55.94, $\mathrm{H}$ 6.78, S 8.30; found C 56.42, H 6.81, S 9.01.

Data for 22: $[\alpha]_{\mathrm{D}}^{24}=+118.8\left(c=0.04, \mathrm{CHCl}_{3}\right)$; $\operatorname{ref}^{[30]}[\alpha]_{\mathrm{D}}^{25}=+100.4$ $(c=1.0) . R_{\mathrm{f}}=0.47\left(\mathrm{CH}_{2} \mathrm{Cl}_{2} / \mathrm{CH}_{3} \mathrm{OH}, 95: 5\right) .{ }^{1} \mathrm{H}$ NMR $(360 \mathrm{MHz}$, $\left.\mathrm{CDCl}_{3}\right): \delta=7.53-7.28(\mathrm{~m}, 5 \mathrm{H}$, arom $), 4.59\left(\mathrm{~d}, J_{1,2}=9.4 \mathrm{~Hz}, 1 \mathrm{H}\right.$, 1-H), 3.90-3.48 (m, $6 \mathrm{H}), 3.30,3.22\left(2 \mathrm{~s}, 6 \mathrm{H}, 2 \mathrm{OCH}_{3}\right.$ BDA), 3.10 $(\mathrm{s}, 1 \mathrm{H}, \mathrm{OH}), 2.45(\mathrm{~s}, 1 \mathrm{H}, \mathrm{OH}), 1.33,1.28\left(2 \mathrm{~s}, 6 \mathrm{H}, 2 \mathrm{CH}_{3} \mathrm{BDA}\right)$ ppm. ${ }^{13} \mathrm{C}$ NMR $\left(90 \mathrm{MHz}, \mathrm{CDCl}_{3}\right): \delta=131.4$ (1 C, $\mathrm{C}_{\mathrm{q}}$ arom), 132.7-128.0 (5 C, arom), 99.6, 99.3 (2 C, $2 \mathrm{C}_{\mathrm{q}}$ BDA), 88.1 (1 C, C1), 77.8, 73.2, 69.1, 65.2 (4 C, skeleton carbons), 61.1 (1 C, C-6), 47.7 (2 C, $2 \mathrm{OCH}_{3}$ BDA), 17.5, 17.4 (2 C, $2 \mathrm{CH}_{3}$ BDA) ppm. MS (MALDI-TOF) $\mathrm{m} / \mathrm{z}=409.11[\mathrm{M}+\mathrm{Na}]^{+} . \mathrm{C}_{18} \mathrm{H}_{26} \mathrm{O}_{7} \mathrm{~S}$ (386.46): calcd. C 55.94, H 6.78, S 8.30; found C 56.21, H 6.84, S 8.51.

Phenyl 2,3-O-(2',3'-Dimethoxybutane-2', 3'-diyl)-4,6-O-(2-naphthyl)methylene-1-thio- $\beta$-D-glucopyranoside (23): Compound 21 (500 mg, $1.29 \mathrm{mmol}$ ) was treated according to method C using naphthaldehyde dimethyl acetal (393 $\mathrm{mg}, 1.94 \mathrm{mmol}, 1.5$ equiv.) and $\mathrm{TsOH}$ ( $50 \mathrm{mg}, 0.258 \mathrm{mmol}, 0.2$ equiv.). Purification by column chromatography on silica gel ( $n$-hexane/EtOAc, 95:5) gave compound 23 (465 $\mathrm{mg}, 68 \%$ ) as a colourless syrup. Unreacted 21 was recovered $(145 \mathrm{mg}, 21 \%)$. Data for 23: $[\alpha]_{\mathrm{D}}^{24}=-123.2(c=0.50$, $\left.\mathrm{CHCl}_{3}\right) . R_{\mathrm{f}}=0.55(n$-hexane/acetone, $7: 3) .{ }^{1} \mathrm{H}$ NMR $(400 \mathrm{MHz}$, $\left.\mathrm{CDCl}_{3}\right): \delta=7.93-7.25(\mathrm{~m}, 12 \mathrm{H}, \operatorname{arom}), 5.68\left(\mathrm{~s}, 1 \mathrm{H}, \mathrm{H}_{\mathrm{ac}}\right), 4.91(\mathrm{~d}$, 
$\left.J_{1,2}=10.1 \mathrm{~Hz}, 1 \mathrm{H}, 1-\mathrm{H}\right), 4.36\left(\mathrm{dd}, J_{\mathrm{gem}}=10.4, J_{5,6}=4.9 \mathrm{~Hz}, 1\right.$ $\mathrm{H}, 6-\mathrm{Ha}), 4.07\left(\mathrm{t}, J_{4,5}=J_{3,4}=9.5 \mathrm{~Hz}, 1 \mathrm{H}, 4-\mathrm{H}\right), 3.85\left(\mathrm{t}, J_{\mathrm{gem}}=\right.$ $\left.J_{5,6 \mathrm{~b}}=10.3 \mathrm{~Hz}, 1 \mathrm{H}, 6-\mathrm{Hb}\right), 3.82-3.77(\mathrm{~m}, 2 \mathrm{H}, 2-\mathrm{H}, 3-\mathrm{H}), 3.59$ $3.53(\mathrm{~m}, 1 \mathrm{H}, 5-\mathrm{H}), 3.29,3.25\left(2 \mathrm{~s}, 6 \mathrm{H}, 2 \mathrm{OCH}_{3} \mathrm{BDA}\right), 1.35,1.34$ $\left(2 \mathrm{~s}, 6 \mathrm{H}, 2 \mathrm{CH}_{3} \mathrm{BDA}\right) \mathrm{ppm} .{ }^{13} \mathrm{C} \mathrm{NMR}\left(100 \mathrm{MHz}, \mathrm{CDCl}_{3}\right): \delta=$ 134.6, 133.6, 133.2, 132.9 (4 C, $\mathrm{C}_{\mathrm{q}}$ arom), 131.9-123.9 (12 C, arom), 101.5 ( $\left.1 \mathrm{C}, \mathrm{C}_{\mathrm{ac}}\right), 100.5,99.7$ (2 C, $2 \mathrm{C}_{\mathrm{q}}$ BDA), 86.2 (1C, C-1), 77.8 (1C, C-2), 71.6 (1C, C-5), 71.2 (1C, C-4), 69.0 (1C, C-3), 68.8 (1C C-6), 48.3, 48.1 (2C, $\left.2 \mathrm{OCH}_{3} \mathrm{BDA}\right), 17.7$ (2C, $\left.2 \mathrm{CH}_{3} \mathrm{BDA}\right) \mathrm{ppm}$. MS (MALDI-TOF) $m / z=547.16[\mathrm{M}+\mathrm{Na}]^{+} . \mathrm{C}_{29} \mathrm{H}_{32} \mathrm{O}_{7} \mathrm{~S}$ (524.19): calcd. C 66.39, H 6.15, S 6.11; found C 66.43, H 6.20, S 6.17.

Phenyl 2,3-O-(2',3'-Dimethoxybutane-2',3'-diyl)-4-O-(2-naphthyl)-

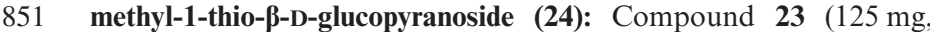
$0.238 \mathrm{mmol}$ ) was converted into 24 by method $\mathrm{D}$ using anhydrous $\mathrm{CH}_{2} \mathrm{Cl}_{2}(350 \mu \mathrm{L})$, anhydrous $\mathrm{Et}_{2} \mathrm{O}(2 \times 170 \mu \mathrm{L}), \mathrm{LiAlH}_{4}(40 \mathrm{mg}$, $1.071 \mathrm{mmol})$, and $\mathrm{AlCl}_{3}(47 \mathrm{mg}, 0.357 \mathrm{mmol})$ at room temperature. Purification by column chromatography on silica gel ( $n$-hexane/ 856 EtOAc, 75:25) gave compound $24(99 \mathrm{mg}, 79 \%)$ as a white foam $[a]_{\mathrm{D}}^{24}=-102.6\left(c=0.04, \mathrm{CHCl}_{3}\right) . R_{\mathrm{f}}=0.42(n$-hexane/EtOAc, 75:25). ${ }^{1} \mathrm{H}$ NMR $\left(400 \mathrm{MHz}, \mathrm{CDCl}_{3}\right): \delta=7.81-7.20(\mathrm{~m}, 12 \mathrm{H}$, arom), $5.09\left(\mathrm{~d}, J_{\text {gem }}=11.3 \mathrm{~Hz}, 1 \mathrm{H}, \mathrm{NAP}-\mathrm{CH}_{2 \mathrm{a}}\right), 4.81(\mathrm{~m}, 2 \mathrm{H}$ NAP-C $\left.H_{2 b}, 1-\mathrm{H}\right), 3.98\left(\mathrm{t}, J_{4,5}=J_{3,4}=9.5 \mathrm{~Hz}, 1 \mathrm{H}, 4-\mathrm{H}\right), 3.86(\mathrm{dd}$, $\left.861 J_{3,4}=12.0, J_{2,3}=2.4 \mathrm{~Hz}, 1 \mathrm{H}, 3-\mathrm{H}\right), 3.74-3.66(\mathrm{~m}, 3 \mathrm{H}, 2-\mathrm{H}, 6-$ Ha,b), 3.47-3.42 (m, $1 \mathrm{H}, 5-\mathrm{H}), 3.31,3.25\left(2 \mathrm{~s}, 6 \mathrm{H}, 2 \mathrm{OCH}_{3}\right.$ BDA), 2.14 (s, $1 \mathrm{H}, \mathrm{C}-6-\mathrm{OH}), 1.37,1.35\left(2 \mathrm{~s}, 6 \mathrm{H}, 2 \mathrm{CH}_{3} \mathrm{BDA}\right) \mathrm{ppm} .{ }^{13} \mathrm{C}$ $\operatorname{NMR}\left(100 \mathrm{MHz}, \mathrm{CDCl}_{3}\right): \delta=135.7,133.3,133.0$ (4 C, $\mathrm{C}_{\mathrm{q}}$ arom), 131.6-126.0 (12 C, arom), 100.2, 99.7 (2 C, $2 \mathrm{C}_{\mathrm{q}}$ BDA), 85.0 (1 C, $866 \mathrm{C}-1), 79.8,75.4,74.6,68.4$ (4 C, skeleton carbons), 75.0 (1 C, NAP$\left.\mathrm{CH}_{2}\right), 62.3$ (1 C, C-6), 48.2, $48.0\left(2 \mathrm{C}, 2 \mathrm{OCH}_{3} \mathrm{BDA}\right), 17.9,17.7$ (2 C, $2 \mathrm{CH}_{3}$ BDA) ppm. MS (MALDI-TOF) $\mathrm{m} / \mathrm{z}=549.21[\mathrm{M}+$ $\mathrm{Na}]^{+} . \mathrm{C}_{29} \mathrm{H}_{34} \mathrm{O}_{7} \mathrm{~S}$ (526.64): calcd. C 66.14, H 6.51, S 6.09; found C $66.23, \mathrm{H} 6.61, \mathrm{~S} 6.16$.

871 Phenyl 2,3-O-(2',3'-Dimethoxybutane-2',3'-diyl)-6-O-(2-naphthyl)methyl-1-thio-p-D-glucopyranoside (25)

Reaction 1: Compound 23 (100 mg, $0.191 \mathrm{mmol})$ was converted into 25 by method $\mathrm{E}$ using $\mathrm{BF}_{3} \cdot \mathrm{Et}_{2} \mathrm{O}$ (1.0 equiv.). The crude product was purified by silica gel chromatography ( $n$-hexane/EtOAc, 65:35) to give $\mathbf{2 5}(69 \mathrm{mg}, 69 \%$ ) as a colourless syrup.

Reaction 2: Compound 23 (165 mg, $0.315 \mathrm{mmol})$ was converted into 25 by method F. Purification by column chromatography on silica gel ( $n$-hexane/acetone, 7:3) gave compound $25(136 \mathrm{mg}, 82 \%)$ as a white foam. $[\alpha]_{\mathrm{D}}^{24}=-107.5\left(c=0.37, \mathrm{CHCl}_{3}\right) . R_{\mathrm{f}}=0.19(n-$ hexane/EtOAc, 65:35). ${ }^{1} \mathrm{H}$ NMR $\left(400 \mathrm{MHz}, \mathrm{CDCl}_{3}\right): \delta=7.83-7.19$ $\left(\mathrm{m}, 12 \mathrm{H}\right.$, arom), $4.81\left(\mathrm{~d}, J_{1,2}=9.8 \mathrm{~Hz}, 1 \mathrm{H}, 1-\mathrm{H}\right), 4.73\left(\mathrm{~d}, J_{\text {gem }}=\right.$ $1.0 \mathrm{~Hz}, 2 \mathrm{H}$, NAP-C $\left.H_{2}\right), 3.86-3.73(\mathrm{~m}, 4 \mathrm{H}), 3.67-3.56(\mathrm{~m}, 2 \mathrm{H})$, $3.28,3.19\left(2 \mathrm{~s}, 6 \mathrm{H}, 2 \mathrm{OCH}_{3} \mathrm{BDA}\right), 2.86(\mathrm{~s}, 1 \mathrm{H}, \mathrm{C}-4-\mathrm{OH}), 1.34$ $1.33\left(2 \mathrm{~s}, 6 \mathrm{H}, 2 \mathrm{CH}_{3} \mathrm{BDA}\right) \mathrm{ppm} .{ }^{13} \mathrm{C} \mathrm{NMR}\left(100 \mathrm{MHz}, \mathrm{CDCl}_{3}\right): \delta$ $886=135.5,133.5,133.3,133.1\left(4 \mathrm{C}, 4 \mathrm{C}_{\mathrm{q}}\right.$ arom $), 131.7-125.7(12 \mathrm{C}$, arom), 100.2, 99.7 (2 C, $2 \mathrm{C}_{\mathrm{q}}$ BDA), 85.2 (1 C, C-1), 79.1, 74.4, 68.8, 67.9 (4 C, skeleton carbons), 73.8 (1 C, NAP- $\left.\mathrm{CH}_{2}\right), 70.2$ (1 C, C-6), 48.2, 48.0 (2 C, $\left.2 \mathrm{OCH}_{3} \mathrm{BDA}\right), 17.7,17.7\left(2 \mathrm{C}, 2 \mathrm{CH}_{3}\right.$ BDA) ppm. MS (MALDI-TOF) $m / z=549.21\left[\mathrm{M}+\mathrm{Na}^{+}\right.$

$891 \mathrm{C}_{29} \mathrm{H}_{34} \mathrm{O}_{7} \mathrm{~S}$ (526.64): calcd. C 66.14, H 6.51, S 6.09; found $\mathrm{C} 66.21$, H 6.59, S 6.17

Methyl 2,3-O-(2',3'-Dimethoxybutane-2', $3^{\prime}$-diyl)-a-D-galactopyranoside (27): Compound 26 (1.00 g, $5.15 \mathrm{mmol})$ was converted into 27 by method B. Purification by column chromatography on silica gel ( $n$-hexane/acetone, 7:3) gave compound $27(1.225 \mathrm{~g}, 77 \%)$ as white crystals, m.p. $81-84^{\circ} \mathrm{C}$; ref. ${ }^{[13 a]}$ m.p. $88-91{ }^{\circ} \mathrm{C}$. $[\alpha]_{\mathrm{D}}^{24}=-32.9$ $\left(c=0.24, \mathrm{CHCl}_{3}\right) . R_{\mathrm{f}}=0.43(n$-hexane/acetone, $7: 3) .{ }^{1} \mathrm{H}$ NMR $\left(400 \mathrm{MHz}, \mathrm{CDCl}_{3}\right): \delta=4.84\left(\mathrm{~d}, J_{1,2}=3.5 \mathrm{~Hz}, 1 \mathrm{H}, 1-\mathrm{H}\right), 4.19(\mathrm{dd}$, $J=10.1, J=3.5 \mathrm{~Hz}, 1 \mathrm{H}), 4.09-4.035(\mathrm{~m}, 2 \mathrm{H}), 3.95-3.81(\mathrm{~m}, 3$
$\mathrm{H}), 3.43\left(\mathrm{~s}, 3 \mathrm{H}, \mathrm{C}-1-\mathrm{OCH}_{3}\right), 3.27,3.26\left(2 \mathrm{~s}, 6 \mathrm{H}, 2 \mathrm{OCH}_{3} \mathrm{BDA}\right)$, $2.97(\mathrm{~s}, 1 \mathrm{H}, \mathrm{OH}), 2.46(\mathrm{~s}, 1 \mathrm{H}, \mathrm{OH}), 1.34,1.31(2 \mathrm{~s}, 6 \mathrm{H}, 2 \mathrm{CH}$ BDA) ppm. ${ }^{13} \mathrm{C}$ NMR $\left(100 \mathrm{MHz}, \mathrm{CDCl}_{3}\right): \delta=100.2,100.1(2 \mathrm{C}$, $2 \mathrm{C}_{\mathrm{q}}$ BDA), 98.4 (1 C, C-1), 70.3, 69.0, 66.3, 65.1 (4 C, skeleton carbons), $62.6(1 \mathrm{C}, \mathrm{C}-6), 55.2\left(1 \mathrm{C}, \mathrm{C}-1-\mathrm{OCH}_{3}\right), 48.0\left(2 \mathrm{C}, 2 \mathrm{OCH}_{3}\right.$ BDA), 17.8, 17.7 (2 C, $2 \mathrm{CH}_{3}$ BDA) ppm. MS (MALDI-TOF): $\mathrm{m} / \mathrm{z}$ $=331.16[\mathrm{M}+\mathrm{Na}]^{+} . \mathrm{C}_{13} \mathrm{H}_{24} \mathrm{O}_{8}$ (308.15): calcd. C 50.64, H 7.85; found $\mathrm{C} 50.71, \mathrm{H} 7.90$

Methyl 4,6-O-Benzylidene-2,3- $O$ - $\left(2^{\prime}, 3^{\prime}\right.$-dimethoxybutane-2', $3^{\prime}$ diyl)- $\boldsymbol{\alpha}$-D-galactopyranoside (28): Compound $27 \quad$ (600 $\mathrm{mg}$, $1.946 \mathrm{mmol}$ ) was converted into 28 by method $\mathrm{C}$ using benzaldehyde dimethyl acetal (444 mg, $2.92 \mathrm{mmol}, 1.5$ equiv.) and $\mathrm{TsOH}$ ( 0.25 equiv.). The crude product was purified by silica gel chromatography ( $n$-hexane/acetone, 8:2) to give $\mathbf{2 8}(513 \mathrm{mg}, 67 \%)$ as white crystals, m.p. $270-273{ }^{\circ} \mathrm{C} .[\alpha]_{\mathrm{D}}^{24}=-3.67\left(c=0.27, \mathrm{CHCl}_{3}\right)$. $R_{\mathrm{f}}=0.33$ ( $n$-hexane/acetone, 8:2). ${ }^{1} \mathrm{H}$ NMR $\left(400 \mathrm{MHz}, \mathrm{CDCl}_{3}\right): \delta$ $=7.55-7.30(\mathrm{~m}, 5 \mathrm{H}$, arom $), 5.57\left(\mathrm{~s}, 1 \mathrm{H}, \mathrm{H}_{\mathrm{ac}}\right), 4.90\left(\mathrm{~d}, J_{1,2}=\right.$ $3.5 \mathrm{~Hz}, 1 \mathrm{H}, 1-\mathrm{H}), 4.35(\mathrm{dd}, J=3.6, J=10.3 \mathrm{~Hz}, 1 \mathrm{H}), 4.26-4.17$ (m, $4 \mathrm{H}), 4.09$ (dd, $J=1.4, J=12.4 \mathrm{~Hz}, 1 \mathrm{H}), 3.44$ (s, $3 \mathrm{H}, \mathrm{C}-1-$ $\left.\mathrm{OCH}_{3}\right), 3.29,3.25\left(2 \mathrm{~s}, 6 \mathrm{H}, 2 \mathrm{OCH}_{3} \mathrm{BDA}\right), 1.34,1.32(2 \mathrm{~s}, 6 \mathrm{H}, 2$ $\mathrm{CH}_{3}$ BDA) ppm. ${ }^{13} \mathrm{C}$ NMR $\left(100 \mathrm{MHz}, \mathrm{CDCl}_{3}\right): \delta=137.8\left(1 \mathrm{C}, \mathrm{C}_{\mathrm{q}}\right.$ arom), 128.7, 128.0, 126.5 (5 C, arom), $100.7\left(1 \mathrm{C}, \mathrm{C}_{\mathrm{ac}}\right), 100.1,99.9$ (2 C, $2 \mathrm{C}_{\mathrm{q}}$ BDA), 98.9 (1 C, C-1), 74.5, 65.1, 64.9, 63.1 (4 C, skeleton carbons), $69.6(1 \mathrm{C}, \mathrm{C}-6), 55.3\left(1 \mathrm{C}, \mathrm{C}-1-\mathrm{OCH}_{3}\right), 47.9,47.9$ (2 $\mathrm{C}, 2 \mathrm{OCH}_{3}$ BDA), 17.8, $17.7\left(2 \mathrm{C}, 2 \mathrm{CH}_{3}\right.$ BDA $)$ ppm. MS (MALDI-TOF): $m / z=419.17\left[\mathrm{M}+\mathrm{Na}^{+} . \mathrm{C}_{20} \mathrm{H}_{28} \mathrm{O}_{8}\right.$ (396.18): calcd. C 60.59 , H 7.12; found C 60.67, H 7.19.

Methyl 4-O-Benzyl-2,3-O-(2', $3^{\prime}$-dimethoxybutane-2', $3^{\prime}$-diyl)-a-Dgalactopyranoside (29): Compound 28 (100 $\mathrm{mg}, 0.252 \mathrm{mmol})$ was converted into 29 by method D using anhydrous $\mathrm{CH}_{2} \mathrm{Cl}_{2}(375 \mu \mathrm{L})$, anhydrous $\mathrm{Et}_{2} \mathrm{O}(2187 \mu \mathrm{L}), \mathrm{LiAlH}_{4}(43 \mathrm{mg}, 1.135 \mathrm{mmol})$, and $\mathrm{AlCl}_{3}(50 \mathrm{mg}, 0.378 \mathrm{mmol})$ at room temperature. Purification by column chromatography on silica gel ( $n$-hexane/acetone, 8:2) gave compound $29(84 \mathrm{mg}, 84 \%)$ as a colourless syrup. $[a]_{\mathrm{D}}^{24}=-65.6(c$ $\left.=0.13, \mathrm{CHCl}_{3}\right) . R_{\mathrm{f}}=0.25(n$-hexane/acetone, $7: 3) .{ }^{1} \mathrm{H} \mathrm{NMR}$ $\left(400 \mathrm{MHz}, \mathrm{CDCl}_{3}\right): \delta=7.45-7.27(\mathrm{~m}, 5 \mathrm{H}$, arom $), 5.00\left(\mathrm{~d}, J_{\text {gem }}=\right.$ $\left.11.2 \mathrm{~Hz}, 1 \mathrm{H}, \mathrm{Ph}-\mathrm{CH}_{2 \mathrm{a}}\right), 4.83\left(\mathrm{~d}, J_{1,2}=3.5 \mathrm{~Hz}, 1 \mathrm{H}, 1-\mathrm{H}\right), 4.63(\mathrm{~d}$, $\left.J_{\text {gem }}=11.3 \mathrm{~Hz}, 1 \mathrm{H}, \mathrm{Ph}-\mathrm{CH}_{2 \mathrm{~b}}\right), 4.34\left(\mathrm{dd}, J_{2,3}=10.6, J_{1,2}=3.6 \mathrm{~Hz}\right.$, $1 \mathrm{H}, 2-\mathrm{H}), 4.13\left(\mathrm{dd}, J_{2,3}=10.6, J_{3,4}=2.5 \mathrm{~Hz}, 1 \mathrm{H}, 3-\mathrm{H}\right), 3.81-3.77$ (m, $3 \mathrm{H}, 4-\mathrm{H}, 6-\mathrm{Ha}, \mathrm{b}), 3.61-3.60$ (m, $1 \mathrm{H}, 5-\mathrm{H}), 3.39$ (s, $3 \mathrm{H}, \mathrm{C}-1-$ $\left.\mathrm{OCH}_{3}\right), 3.29,3.28\left(2 \mathrm{~s}, 6 \mathrm{H}, 2 \mathrm{OCH}_{3} \mathrm{BDA}\right), 2.19(\mathrm{~s}, 1 \mathrm{H}, \mathrm{OH}), 1.35$, $1.33\left(2 \mathrm{~s}, 6 \mathrm{H}, 2 \mathrm{CH}_{3} \mathrm{BDA}\right) \mathrm{ppm} .{ }^{13} \mathrm{C} \mathrm{NMR}\left(100 \mathrm{MHz}, \mathrm{CDCl}_{3}\right): \delta$ $=138.5\left(1 \mathrm{C}, \mathrm{C}_{\mathrm{q}}\right.$ arom $), 128.8,128.4,127.9$ (5 C, arom), 99.9, 99.6 (2 C, $2 \mathrm{C}_{\mathrm{q}}$ BDA), 98.5 (1 C, C-1), 74.8, 70.9, 67.9, 65.8 (4 C, skeleton carbons), $74.2\left(1 \mathrm{C}, \mathrm{Ph}-\mathrm{CH}_{2}\right), 62.6(1 \mathrm{C}, \mathrm{C}-6), 55.2(1 \mathrm{C}, \mathrm{C}-$ $\left.1-\mathrm{OCH}_{3}\right), 47.9,47.9\left(2 \mathrm{C}, 2 \mathrm{OCH}_{3} \mathrm{BDA}\right), 17.9,17.8\left(2 \mathrm{C}, 2 \mathrm{CH}_{3}\right.$ BDA) ppm. MS (MALDI-TOF): $m / z=421.20\left[\mathrm{M}+\mathrm{Na}^{+}\right.$. $\mathrm{C}_{20} \mathrm{H}_{30} \mathrm{O}_{8}$ (398.19): calcd. C 60.29, H 7.59; found C 60.34, H 7.63.

Methyl 6- $O$-Benzyl-2,3- $O$-(butane-2' $\mathbf{3}^{\prime}$-diyl)- $\alpha$-D-galactopyranoside (30): Compound $28(100 \mathrm{mg}, 0.252 \mathrm{mmol})$ was converted into $\mathbf{3 0}$ by method $\mathrm{E}$ using $\mathrm{BF}_{3} \cdot \mathrm{Et}_{2} \mathrm{O}$ (2.0 equiv.) and molecular sieves ( $4 \AA$; $0.5 \mathrm{~g}$ ). The crude product was purified by silica gel chromatography ( $n$-hexane/acetone, $8: 2)$ to give $\mathbf{3 0}(8 \mathrm{mg}, 8 \%)$ as a colourless syrup. $[a]_{\mathrm{D}}^{24}=+112.5(c=0.02, \mathrm{MeOH}) . R_{\mathrm{f}}=0.27(n$-hexane/acetone, 8:2). ${ }^{1} \mathrm{H}$ NMR $\left(360 \mathrm{MHz}, \mathrm{CDCl}_{3}\right): \delta=7.37-7.26(\mathrm{~m}, 5 \mathrm{H}$, arom), 4.95 $\left(\mathrm{d}, J_{\mathrm{gem}}=11.7 \mathrm{~Hz}, 1 \mathrm{H}, \mathrm{Ph}-\mathrm{CH}_{2 \mathrm{a}}\right), 4.87\left(\mathrm{~d}, J_{1,2}=3.6 \mathrm{~Hz}, 1 \mathrm{H}, 1-\right.$ $\mathrm{H}), 4.64\left(\mathrm{~d}, J_{\text {gem }}=11.7 \mathrm{~Hz}, 1 \mathrm{H}, \mathrm{Ph}-\mathrm{CH}_{2 \mathrm{~b}}\right), 4.00\left(\mathrm{dd}, J_{2,3}=10.0\right.$, $\left.J_{1,2}=3.7 \mathrm{~Hz}, 1 \mathrm{H}, 2-\mathrm{H}\right), 3.88\left(\mathrm{dd}, J_{2,3}=10.0, J_{3,4}=2.6 \mathrm{~Hz}, 1 \mathrm{H}\right.$, 3-H), 3.81-3.77 (m, 4 H, 4-H, 6-Ha,b, CHa butane-2',3'-diyl), 3.64-3.55 (m, 2 H, 5-H, CHb butane-2', $3^{\prime}$-diyl), 3.41 (s, 3 H, C-1$\left.\mathrm{OCH}_{3}\right), 1.88(\mathrm{~s}, 1 \mathrm{H}, \mathrm{OH}), 1.19-1.15\left(\mathrm{~m}, 6 \mathrm{H}, 2 \mathrm{CH}_{3}\right.$ butane-2', $3^{\prime}-$ diyl) ppm. ${ }^{13} \mathrm{C}$ NMR $\left(90 \mathrm{MHz}, \mathrm{CDCl}_{3}\right): \delta=128.7,128.6,128.1(5$
901 
C, arom), 98.5 (1 C, C-1), 78.2, 77.3, 75.2, 74.9, 73.8, 70.7 (6 C, 4 skeleton carbons, $2 \mathrm{CH}$ butane-2', $3^{\prime}$-diyl), $74.3\left(1 \mathrm{C}, \mathrm{Ph}-\mathrm{CH}_{2}\right), 62.8$ $(1 \mathrm{C}, \mathrm{C}-6), 55.4\left(1 \mathrm{C}, \mathrm{C}-1-\mathrm{OCH}_{3}\right), 17.7,17.4\left(2 \mathrm{C}, 2 \mathrm{CH}_{3}\right.$ butane$2^{\prime}, 3^{\prime}$-diyl) ppm. MS (MALDI-TOF): $\mathrm{m} / z=361.19[\mathrm{M}+\mathrm{Na}]^{+}$. $\mathrm{C}_{18} \mathrm{H}_{26} \mathrm{O}_{6}$ (338.17): calcd. C 63.89, H 7.74; found $\mathrm{C} 63.93, \mathrm{H}$ 7.78.

Methyl 4,6- $O$-Benzylidene-2,3- $O$-(butane-2',3'-diyl)- $\alpha$-D-galactopyranoside (31): Compound $28(230 \mathrm{mg}, 0.580 \mathrm{mmol})$ was treated according to method $\mathrm{E}$ using $\mathrm{BF}_{3} \cdot \mathrm{Et}_{2} \mathrm{O}$ (1.0 equiv.) and molecular sieves $(4 \AA ; 0.5 \mathrm{~g})$. The crude product was purified by silica gel chromatography $\left(\mathrm{CH}_{2} \mathrm{Cl}_{2} / \mathrm{EtOAc}, 8: 2\right)$ to give $\mathbf{3 1}(42 \mathrm{mg}, 18 \%)$ as a colourless syrup. Unreacted $\mathbf{2 8}$ was recovered (28 mg, 12\%). Data for 31: $[a]_{\mathrm{D}}^{24}=+60.1\left(c=0.08, \mathrm{CHCl}_{3}\right) . R_{\mathrm{f}}=0.59\left(\mathrm{CH}_{2} \mathrm{Cl}_{2} / \mathrm{EtOAc}\right.$, 85:15). ${ }^{1} \mathrm{H} \mathrm{NMR}\left(400 \mathrm{MHz}, \mathrm{CDCl}_{3}\right): \delta=7.54-7.33$ (m, $5 \mathrm{H}$, arom),

$9765.56\left(\mathrm{~s}, 1 \mathrm{H}, \mathrm{H}_{\mathrm{ac}}\right), 4.96\left(\mathrm{~d}, J_{1,2}=3.5 \mathrm{~Hz}, 1 \mathrm{H}, 1-\mathrm{H}\right), 4.27-4.24(\mathrm{~m}$, $2 \mathrm{H}), 4.11-4.06(\mathrm{~m}, 3 \mathrm{H}), 3.91\left(\mathrm{dd}, J_{2,3}=10.1, J_{3,4}=3.3 \mathrm{~Hz}, 1 \mathrm{H}\right)$, $3.69(\mathrm{~s}, 1 \mathrm{H}), 3.46\left(\mathrm{~s}, 4 \mathrm{H}, 1 \mathrm{CH}\right.$ butane-2',3'-diyl, C-1-OCH $\left.\mathrm{H}_{3}\right)$, 1.17-1.14 (m, $6 \mathrm{H}, 2 \mathrm{CH}_{3}$ butane- $2^{\prime}, 3^{\prime}$-diyl) ppm. ${ }^{13} \mathrm{C}$ NMR $\left(100 \mathrm{MHz}, \mathrm{CDCl}_{3}\right): \delta=138.0\left(1 \mathrm{C}, \mathrm{C}_{\mathrm{q}}\right.$ arom $), 128.9,128.1,126.6$ 981 (5 C, arom), 101.0 (1 C, $\left.\mathrm{C}_{\mathrm{ac}}\right), 99.0$ (1 C, C-1), 77.7, 77.6, 74.7, 72.7, 72.5, 63.1 (6 C, 4 skeleton carbons, $2 \mathrm{CH}$ butane-2',3'-diyl), 69.7 (1 C, C-6), 55.5 (1 C, C-1-OCH $)_{3}, 17.4$ (2 C, $2 \mathrm{CH}_{3}$ butane-2', 3'diyl) ppm. MS (MALDI-TOF): $m / z=359.27[\mathrm{M}+\mathrm{Na}]^{+} . \mathrm{C}_{18} \mathrm{H}_{24} \mathrm{O}_{6}$ (336.38): calcd. C 64.27, H 7.19; found C 64.34, H 7.23.

Methyl 6-O-Benzyl-2,3-O-(2',3'-dimethoxybutane-2', $3^{\prime}$-diyl)- $\alpha$-Dgalactopyranoside (32): Compound $28(230 \mathrm{mg}, 0.580 \mathrm{mmol})$ was treated according to method F. Purification by column chromatography on silica gel $\left(\mathrm{CH}_{2} \mathrm{Cl}_{2} / \mathrm{EtOAc}, 8: 2\right)$ gave compound 32 (169 $\mathrm{mg}, 73 \%)$ as a white foam, and compound $29(17 \mathrm{mg}, 7 \%)$ as a white foam. Data for 32: $[\alpha]_{\mathrm{D}}^{24}=-11.5\left(c=0.15, \mathrm{CHCl}_{3}\right) . R_{\mathrm{f}}=$ $0.53\left(\mathrm{CH}_{2} \mathrm{Cl}_{2} /\right.$ EtOAc, 8:2). ${ }^{1} \mathrm{H}$ NMR $\left(400 \mathrm{MHz}, \mathrm{CDCl}_{3}\right): \delta=7.35$ $7.27\left(\mathrm{~m}, 5 \mathrm{H}\right.$, arom), $4.83\left(\mathrm{~d}, J_{1,2}=3.5 \mathrm{~Hz}, 1 \mathrm{H}, 1-\mathrm{H}\right), 4.59\left(\mathrm{~d}, J_{\text {gem }}\right.$ $\left.=3.4 \mathrm{~Hz}, 2 \mathrm{H}, \mathrm{Ph}-\mathrm{CH}_{2}\right), 4.21\left(\mathrm{dd}, J_{2,3}=10.4, J_{1,2}=3.6 \mathrm{~Hz}, 1 \mathrm{H}\right.$, $2-\mathrm{H}), 4.06\left(\mathrm{dd}, J_{2,3}=10.4, J_{3,4}=3.1 \mathrm{~Hz}, 1 \mathrm{H}, 3-\mathrm{H}\right), 4.02-4.0(\mathrm{~m}$, $\left.=9.9, J_{5,6 \mathrm{a}}=5.6 \mathrm{~Hz}, 1 \mathrm{H}, 6-\mathrm{Ha}\right), 3.73-3.68(\mathrm{~m}, 1 \mathrm{H}, 6-\mathrm{Hb}), 3.43$ (s, $\left.3 \mathrm{H}, \mathrm{C}-1-\mathrm{OCH}_{3}\right), 3.25,3.24\left(2 \mathrm{~s}, 6 \mathrm{H}, 2 \mathrm{OCH}_{3} \mathrm{BDA}\right), 2.67$ (s, 1 $\mathrm{H}, \mathrm{OH}), 1.33,1.31\left(2 \mathrm{~s}, 6 \mathrm{H}, 2 \mathrm{CH}_{3}\right.$ BDA $) \mathrm{ppm} .{ }^{13} \mathrm{C} \mathrm{NMR}$ $\left(100 \mathrm{MHz}, \mathrm{CDCl}_{3}\right): \delta=138.1\left(1 \mathrm{C}, \mathrm{C}_{\mathrm{q}}\right.$ arom $), 128.5,127.8(5 \mathrm{C}$,

1001 arom), 100.2 (2 C, $\left.2 \mathrm{C}_{\mathrm{q}} \mathrm{BDA}\right), 98.4(1 \mathrm{C}, \mathrm{C}-1), 73.7\left(1 \mathrm{C}, \mathrm{Ph}-\mathrm{CH}_{2}\right)$, 69.6 (1 C, C-6), 69.5 (1 C, C-5), 68.4 (1 C, C-4), 66.5 (1 C, C-3), $65.2(1 \mathrm{C}, \mathrm{C}-2), 55.3\left(1 \mathrm{C}, \mathrm{C}-1-\mathrm{OCH}_{3}\right), 48.0\left(2 \mathrm{C}, 2 \mathrm{OCH}_{3} \mathrm{BDA}\right)$, 17.9, 17.8 (2 C, $2 \mathrm{CH}_{3}$ BDA) ppm. MS (MALDI-TOF): $\mathrm{m} / \mathrm{z}=$ $421.30[\mathrm{M}+\mathrm{Na}]^{+} . \mathrm{C}_{20} \mathrm{H}_{30} \mathrm{O}_{8}$ (398.19): calcd. C 60.29, H 7.59;

1006 found $\mathrm{C} 60.36, \mathrm{H} 7.64$.

Supporting Information (see footnote on the first page of this article): Crystallographic data for compound 17 ; copies of ${ }^{1} \mathrm{H}$ and ${ }^{13} \mathrm{C}$ NMR spectra for all described compounds.

\section{Acknowledgments}

1011 The authors gratefully acknowledge financial support for this research from the Hungarian Research Fund (OTKA K 109208) and the Mizutani Foundation for Glycoscience (150091). This research was also supported by the European Union (EU) and the State of Hungary, cofinanced by the European Social Fund in the frame-

1016 work of TÁMOP 4.2.4. A/2-11-1-2012-0001, National Excellence Program. The authors wish to thank Dr. Attila Bényei for the Xray measurement.

[1] P. G. M. Wuts, T. W. Greene, Protective Groups in Organic Synthesis John Wiley \& Sons, Hoboken, New Jersey, 2007.
2] P. J. Kociensky, Protecting Groups, Thieme, Stuttgart, Germany, 2004

[3] S. Oscarson, in: The Organic Chemistry of Sugars (Eds.: D. A Levy, P. Fügedi), CRC Press, Boca Raton, USA, 2006, p. 53 87.

[4] I. Bajza, A. Borbás, A. Lipták, in: Comprehensive Glycoscience, vol. 1 (Ed.: J. P. Kamerling), Elsevier, Oxford, UK, 2007, p. 203-259.

[5] J. D. C. Codée, A. Ali, H. S. Overkleeft, G. A. van der Marel, C. R. Chim. 2011, 14, 178-193.

[6] A. Francais, D. Urban, J.-M. Beau, Angew. Chem. Int. Ed 2007, 46, 8662-8665; Angew. Chem. 2007, 119, 8816-8819.

[7] C. C. Wang, J. C. Lee, S. Y. Luo, S. S. Kulkarni, Y. W. Huang, C. C. Lee, K. L. Chang, S. C. Hung, Nature 2007, 446, 896899.

[8] H. W. Hsieh, M. W. Schombs, J. Gervay-Hague, J. Org. Chem. 2013, 78, 9677-9688.

[9] R. E. J. N. Litjens, L. J. van den Bos, J. D. C. Codée, H. S. Overkleeft, G. A. van der Marel, Carbohydr. Res. 2007, 342, 419429.

[10] a) R. Johnsson, M. Ohlin, U. Ellervik, J. Org. Chem. 2010, 75, 8003-8011; b) M. Ohlin, R. Johnsson, U. Ellervik, Carbohydr. Res. 2011, 346, 1358-1370.

[11] S. V. Ley, R. Leslie, P. D. Tiffin, M. Woods, Tetrahedron Lett 1992, 33, 4767-4770

[12] S. V. Ley, H. W. M. Priepke, S. L. Warriner, Angew. Chem. Int. Ed. Engl. 1994, 33, 2290-2292; Angew. Chem. 1994, 106, 2410 2412.

[13] a) J.-L. Montchamp, F. Tian, M. E. Hart, J. W. Frost, J. Org. Chem. 1996, 61, 3897-3899; b) A. Hense, S. V. Ley, H. M. I Osborn, D. R. Owen, J.-F. Poisson, S. L. Warriner, K. E. Wesson, J. Chem. Soc. Perkin Trans. 1 1997, 2023-2031.

[14] a) S. V. Ley, H. W. M. Priepke, Angew. Chem. Int. Ed. Engl. 1994, 33, 2292-2294; Angew. Chem. 1994, 106, 2412-2414; b) S. V. Ley, D. K. Baeschlin, D. J. Dixon, A. C. Foster, S. J. Ince, H. W. M. Priepke, D. J. Reynolds, Chem. Rev. 2001, 101, 5380

[15] A. M. Gómez, in: Reactivity Tuning in Oligosaccharide Assembly, Topics Curr. Chem. vol. 301 (Eds.: B. Fraser-Reid, J. C. López), Springer, Heidelberg, Germany, 2011, p. 31-68.

[16] C. W. Andrews, R. Rodebaugh, B. Fraser-Reid, J. Org. Chem. 1996, 61, 5280-5289.

[17] H. Liu, R. Nasi, K. Jayakanthan, L. Sim, H. Heipel, D. R Rose, B. M. Pinto, J. Org. Chem. 2007, 72, 6562-6572.

[18] T. K. M. Shing, T. Luk, C. M. Lee, Tetrahedron 2006, 62, 6621 6629.

[19] D. Crich, V. Subramanian, T. K. Hutton, Tetrahedron 2007, 63 , 5042-5049.

[20] S. D. Debenham, E. J. Toone, Tetrahedron: Asymmetry 2000, $11,385-387$.

[21] P. J. Garegg, H. Hultberg, Carbohydr. Res. 1981, 93, C10-C11.

[22] S. A. Nepogodiev, S. Dedola, L. Marmuse, M. T. De Oliveira, R. A. Field, Carbohydr. Res. 2007, 342, 529-540.

[23] A. Lipták, I. Jodál, P. Nánási, Carbohydr. Res. 1975, 44, 1-11.

[24] M. Herczeg, L. Lázár, M. Ohlin, A. Borbás, in: Carbohydrate Chemistry: Proven Synthetic Methods, vol. 2 (Eds.: P. Kovac, G. van der Marel, J. Codée), CRC Press, Boca Raton, USA, 2014, p. 11-18

[25] a) A. Lipták, A. Borbás, L. Jánossy, L. Szilágyi, Tetrahedron Lett. 2000, 41, 4949-4953; b) A. Borbás, Z. B. Szabó, L. Szilágyi, A. Bényei, A. Lipták, Tetrahedron 2002, 58, 5723-5732.

[26] a) M. Herczeg, L. Lázár, A. Borbás, A. Lipták, S. Antus, Org. Lett. 2009, 11, 2619-2622; b) Zs. Jakab, A. Fekete, A. Borbás, A. Lipták, S. Antus, Tetrahedron 2010, 66, 2404-2414.

[27] M. P. DeNinno, J. B. Etienne, K. C. Duplantier, Tetrahedron Lett. 1995, 36, 669-672.

[28] M. Ek, P. J. Garegg, H. Hultberg, S. Oscarson, J. Carbohydr Chem. 1983, 2, 305-311.

[29] a) A. Lipták, A. Borbás, L. Jánossy, L. Szilágyi, Tetrahedron Lett. 2000, 41, 4949-4953; b) A. Borbás, Z. B. Szabó, L. 


\section{FULL PAPER}

Jánossy, ?. Szilágyi, A. Bényei, A. Lipták, Tetrahedron 2002, 58, 5723-5732 ((<=Author: please check the names) $)$

[30] D. Crich, P. Jayalath, J. Org. Chem. 2005, 70, 7252-7259.
[31] M. Herczeg, E. Mező, D. Eszenyi, L. Lázár, M. Csávás, I. Bereczki, S. Antus, A. Borbás, Eur. J. Org. Chem. 2013, 5570- 1096 5573

[32] J. Möker, J. Thiem, Carbohydr. Res. 2012, 348, 14-26.

Received: June 4, 2015 
1101 The reductive cleavage of various arylmethylene acetals in the presence of butane diacetals was studied for the first time. Three reagent systems were used to gain ac-

1106 cess to either 4-hydroxy or 6-hydroxy glycoside derivatives. With the proper choice of reagents, benzylidene-type acetals can be

1111 opened regio- and chemoselectively in high yields.

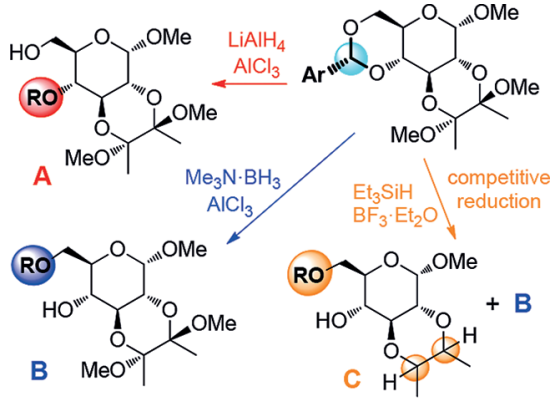

$\mathbf{R}=\mathrm{NAP}(2-$-naphthylmethyl) $/ \mathrm{Bn} / \mathrm{PMB}$ $\mathrm{Ar}=\mathrm{Np}(2$-napthyl) $/ \mathrm{Ph} / p$-MeOPh
M. Herczeg, F. Demeter, E. Mező, M. Pap, A. Borbás*

1-13

Simultaneous Application of Arylmethylene Acetal and Butane Diacetal Groups for Protection of Hexopyranosides: Synthesis and Chemoselective Ring-Opening Reactions

Keywords: Carbohydrates / Acetals / Ring opening / Reduction / Protecting groups / Chemoselectivity 